NBER WORKING PAPER SERIES

\title{
INCOME INEQUALITY AND SOCIAL PREFERENCES FOR REDISTRIBUTION AND COMPENSATION DIFFERENTIALS
}

\author{
William R. Kerr \\ Working Paper 17701 \\ http://www.nber.org/papers/w17701 \\ NATIONAL BUREAU OF ECONOMIC RESEARCH \\ 1050 Massachusetts Avenue \\ Cambridge, MA 02138 \\ December 2011
}

Comments are appreciated and can be sent to wkerr@hbs.edu. I thank Daron Acemoglu, David Autor, Emek Basker, Roland Benabou, Koen Caminada, Joseph Kerr, Ashley Lester, Jo Thori Lind, Erzo Luttmer, Byron Lutz, Rohini Pande, Thomas Piketty, James Snyder, and seminar participants for helpful comments and discussions. The views expressed herein are those of the author and do not necessarily reflect the views of the National Bureau of Economic Research.

NBER working papers are circulated for discussion and comment purposes. They have not been peerreviewed or been subject to the review by the NBER Board of Directors that accompanies official NBER publications.

(C) 2011 by William R. Kerr. All rights reserved. Short sections of text, not to exceed two paragraphs, may be quoted without explicit permission provided that full credit, including $\bigcirc$ notice, is given to the source. 
Income Inequality and Social Preferences for Redistribution and Compensation Differentials

William R. Kerr

NBER Working Paper No. 17701

December 2011

JEL No. D31,D33,D61,D63,D64,D72,H23,H53,I38,J31,R11

\begin{abstract}
$\underline{\text { ABSTRACT }}$
In cross-sectional studies, countries with greater income inequality typically exhibit less support for government-led redistribution and greater acceptance of wage inequality (e.g., United States versus Western Europe). If individual nations evolve along this pattern, a vicious cycle could form with reduced social concern amplifying primal increases in inequality due to forces like skill-biased technical change. Exploring movements around these long-term levels, however, this study finds mixed evidence regarding the vicious cycle hypothesis. On one hand, larger compensation differentials are accepted as inequality grows. This growth in differentials is of a smaller magnitude than the actual increase in inequality, but it is nonetheless positive and substantial in size. Weighing against this, growth in inequality is met with greater support for government-led redistribution to the poor. These patterns suggest that short-run inequality shocks can be reinforced in the labor market but do not result in weaker political preferences for redistribution.
\end{abstract}

William R. Kerr

Harvard Business School

Rock Center 212

Soldiers Field

Boston, MA 02163

and NBER

wkerr@hbs.edu 


\section{Introduction}

Accounting for the substantial increase in wage and income inequality over the last three decades is a central theme of recent economic research. The bulk of the literature focuses on forces operating within the labor market on the supply and demand for skilled workers. These include the slower growth rate in the supply of educated workers, the introduction of labor-saving production and computing technologies, and capital deepening. Others researchers consider structural changes of the labor market itself, like the decline of institutions and policies that have historically compressed the wage structure (e.g., unions, minimum wages) and the proliferation of "superstar" labor markets where top performers earn disproportionate sums to those just behind them. The potential erosion of social preferences regarding compensation inequality and redistribution is also widely discussed. For the United States, particular emphasis is placed on the explosion in executive pay and deepening within-establishment inequality. ${ }^{1}$

While the early work considers each of these determinants in isolation, it is increasingly clear that the interactions among the factors bear significant responsibility. Moreover, a greater potential for the entrenchment or amplification of inequality exists in this general-equilibrium setting. ${ }^{2}$ Taking skill-biased technical change as an example, its individual effect on inequality will be checked in the long-run as firms substitute towards cheaper factors of production or labor supplies adjust. If the bias is sufficient, however, the technical change and its concomitant increase in inequality may also prompt lasting changes in the structure of the labor market (e.g., deunionization, increased segregation of skilled workers) that magnify its solitary effect. Of course, interactions can alternatively dampen inequality shocks.

This potential for amplification is particularly strong for social preferences regarding income equalization. First, if changes in inequality directly influence ideology, then social preferences are a propagation channel for any shock to the income distribution, regardless of the source. Second, of all the factors discussed, social attitudes are the least governed (if at all) by market-like mechanisms that can retard excessive changes. The potential thus exists for the formation of a "vicious cycle" where increases in disparity weaken concern for wage equality or redistribution. This weakened concern affords greater future compensation differentials, a shrinking of the welfare state, and so on that further increase inequality and again shift preferences. Alternatively, changes in social preferences can counteract inequality increases.

Support for the vicious-cycle hypothesis can be taken from the cross-sectional distributions

\footnotetext{
${ }^{1}$ A small sample of the work on these inequality determinants includes Rosen (1981); Bok (1993); Berman, Bound, and Griliches (1994); Frank and Cook (1995); Katz and Murphy (1995); DiNardo, Fortin, and Lemieux (1996); Autor, Katz, and Krueger (1998); Lee (1999); Buchinsky and Hunt (1999); Krusell et. al. (2000); Card (2001); Card and Lemieux (2001); Acemoglu (2002); Card and DiNardo (2002); Rotemberg (2002); Clark (2003); Piketty and Saez (2003); Card, Lemieux, and Riddell (2004); Guadalupe (2007); Autor, Katz, and Kearney (2008); Lemieux (2008); Autor, Manning, and Smith (2010); and Autor and Dorn (2011). Gordon and DewBecker (2008), Heathcote, Perri, and Violante (2010), and Acemoglu and Autor (2011) provide recent surveys of various inequality determinants.

${ }^{2}$ For example, Acemoglu, Aghion, and Violante (2001); Benabou (2002); Hassler et. al. (2003); and Guvenen, Kuruscu, and Ozkan (2011).
} 
of countries (particularly long-term OECD members) and regions of the United States. Nations with greater income inequality typically demonstrate less support for redistribution and greater acceptance of wage inequality than their more-equal counterparts. While the evolution of countries or regions along this pattern would be consistent with hypotheses of reduced social concern, this response is not guaranteed as many primal factors determining these long-term ideology positions (e.g., beliefs regarding social mobility) may be stable. ${ }^{3}$ The empirical response of social preferences to changes in inequality has yet to be explored systematically.

This paper investigates this question by focusing on short-term movements in inequality and social attitudes around the long-term level of each country or United States region. A fixed-effect estimation strategy removes permanent differences in inequality and redistribution philosophies, as well as common time trends. The contribution of this study is to characterize how the resulting longitudinal responses resemble and differ from the cross-sectional pattern. How responses differ by income class and neighborhood racial heterogeneity is also considered. ${ }^{4}$ A first set of international results are drawn from a panel of countries repeatedly surveyed by the International Social Survey Programme (ISSP) and the World Value Survey (WVS). Complementary results and extensions are developed through regional variation in the United States captured by the General Social Survey (GSS). To establish causality, an instrumentvariable specification that exploits exogenous changes in the real federal minimum-wage rate interacted with predetermined regional characteristics is also employed.

The results of this study provide mixed evidence regarding the vicious-cycle hypothesis. On one hand, larger compensation differentials are accepted as inequality grows. This growth in wage differentials is of a smaller magnitude than the actual increase in inequality, but it is nonetheless positive and substantial in size. On the other hand, growth in inequality is met with greater concern over inequality, greater support for government-led redistribution to the poor, and greater support for more-progressive taxation. This is particularly true for inequality in the bottom half of the income distribution. While greater class conflict is perceived along income dimensions, the increases in support for redistribution among wealthy individuals are as strong as those of poorer individuals. These patterns suggest that short-run inequality shocks can be reinforced in the labor market, and that changes in compensation differentials due to changing factors of production are only modestly retarded by social preferences. By contrast, inequality growth does not result in weaker political preferences for redistribution, suggesting that the policy channel alone is unlikely to prompt a vicious cycle that amplifies primal inequality

\footnotetext{
${ }^{3}$ The determinants of this cross-sectional pattern have been a frequent and lively political-economy topic since at least de Tocqueville. Alesina, Glaeser, and Sacerdote (2001) and Glaeser (2006) offer broad studies of why the United States has both higher inequality and a smaller welfare state than Western Europe, including appropriate references.

${ }^{4}$ Political-economy models differ in their predictions of how responses to inequality changes vary by income class. Piketty (1995) constructs a Rawlsian model where increases in the inequality of opportunity, holding fixed beliefs regarding the incentive costs of effort, promote greater support for redistribution independent of current income. On the other hand, the standard median-voter model (e.g., Meltzer and Richards 1981) suggests increases in inequality lead to a divergence in preferences for redistribution as gaps to the median income widen.
} 
changes.

Before proceeding to the analysis, it is important to distinguish preferences regarding inequality from other factors that influence perceptions of distributive justice. Political economists have long considered how beliefs regarding the determinants of success affect attitudes towards redistribution. Individuals and societies who believe hard work and effort are more important for outcomes than luck or ancestry often choose systems characterized by higher inequality and lower redistribution. ${ }^{5}$ Past mobility experiences and future expectations of social position are also significant for attitudes towards income equalization. ${ }^{6}$ If the forces driving higher inequality also alter these underlying beliefs, then social preferences for equality may weaken. The analysis presented below controls for changes in these social-mobility beliefs to isolate the effect of inequality, and additional research needs to evaluate whether other amplification mechanisms operate through these channels.

Section 2 of this paper presents evidence using variations across countries in inequality levels and social preferences. Section 3 then considers regional variation in the United States, while Section 4 refines the United States findings through an instrumental-variable specification combining exogenous changes in the federal minimum wage with predetermined regional characteristics. The final section concludes.

\section{Preferences in International Surveys}

The international portion of this study focuses on how social attitudes towards redistribution respond to changes in national income inequality. Evidence is drawn from the International Social Survey Programme (ISSP) and the World Value Survey (WVS) using fixed-effects estimations that combine repeated opinion surveys with aggregate inequality metrics. The data structure and empirical approach are first described, followed by the estimation results and a discussion of the results and identification.

\subsection{ISSP and WVS Data Structure}

The ISSP conducts annual surveys in member countries (38 nations in 1999) on rotating topics ranging from religion to environmental protection. This study primarily considers questions that were included in the 1987, 1992, and 1999 Social Inequality module. Responses to three complementary questions proxy social preferences for government-led income redistribution, the first considering the responsibility of the government in the transfer of income (Government

\footnotetext{
${ }^{5}$ Alesina and Angeletos (2005) demonstrate how differences in these beliefs can create multiple equilibria among otherwise similar economies, as rational agents select taxation and redistribution policies (and their associated distortions) that fulfill their original expectations. Benabou and Tirole (2006) develop a related general-equilibrium model where different beliefs regarding how just the world is create two distinct redistribution states. Guvenen, Kuruscu, and Ozkan (2011) consider the general equilibrium of human capital investments and redistribution policies.

${ }^{6}$ For example, Piketty (1995); Benabou and Ok (2001); Fong (2001, 2006); and Alesina and La Ferrara (2005).
} 
Responsibility), the second focusing on the progressive nature of taxation (Progressive Taxation), and the last focusing on the acceptability of current income differences (Inequality Acceptance). Higher responses on a five-point scale indicate greater support for government intervention, greater support for more progressive taxation, and greater concern over income differences.

Respondents are also asked their opinions on the appropriate salaries for a variety of occupations. Instructions request preferences be pre-tax and regardless of perceptions of current pay scales. From these responses, a Proposed Doctor-Unskilled Worker Wage Ratio is developed as the log ratio of the wages ascribed for a "doctor in general practice" and an "unskilled worker in a factory." A higher ratio indicates a wider wage distribution (i.e., a log ratio of zero would indicate unskilled workers and doctors should earn the same amount), while a lower ratio indicates less support for compensation differentials.

Finally, two questions regarding the presence of conflicts between social groups are considered. The first, focusing on conflicts between the poor and the rich (Poor-Rich Conflict), is used to validate respondents' awareness of the inequality in their countries, while a second question regarding conflict between young and old people is considered as a falsification exercise (YoungOld Conflict). A higher score on a four-point scale indicates a greater perception of conflict.

As a complement to the ISSP, responses to a question included in the 1990, 1995, and 2000 rounds of the WVS are studied. For this question (WVS Income Equalization) respondents are asked to rate their views regarding income equalization, with a higher score on a ten-point scale expressing greater concern. Table 1 details the countries included, sample sizes, and average responses to these questions for both surveys. The unpublished Data Appendix describes in detail the wording of each question.

As a final ingredient, this study estimates changes in national income inequality using log gini series constructed from the United Nations Development Programme's World Income Inequality Database (WIID), the Luxembourg Income Study (LIS), Deininger and Squire (1996), Gottschalk and Smeeding (2000), Atkinson and Brandolini (2001), and various national statistics agencies. With a few exceptions, these gini estimates are estimated with national samples of dis-

posable (after-transfers) household income and lagged one year. The Data Appendix documents the international series constructed and the techniques employed.

\subsection{Empirical Estimation Strategy}

Figure 1 illustrates the main findings of the study. Panel 1A plots the average response by country to the Government Responsibility question in the 1992 ISSP survey against the log inequality level in the country. The trend line indicates that greater inequality is associated with weaker support for redistribution. Panel 1B plots the average proposed wage ratio for a doctor vs. unskilled worker. Respondents in countries with greater inequality propose a wider wage distribution, too. These cross-sectional patterns have been frequently documented, and both patterns could be taken as evidence that a vicious cycle could emerge with growth inequality 
prompting changes in preferences that further amplify the original increase.

The patterns evident in the cross-sections, however, do not necessarily dictate the movement of countries over time. Panels 1C and 1D consider changes in preferences and inequality from 1992 to the 1999 ISSP survey. In Panel 1C, increased inequality is associated with greater redistribution support, in contrast to Panel 1A. Societies experiencing increases in inequality become more concerned about income differences and assign an increasing responsibility to the government for transferring income. Thus, within-country shifts in policy preferences for redistribution do not mirror cross-country patterns, perhaps because other factors that affect redistribution preferences are not being influenced (e.g., belief about determinants of success or mobility). Yet, Panel 1D does show that respondents propose a wider wage distribution after increases in inequality. The within-country and across-country patterns are much more similar with respect to preferences regarding appropriate wage dispersion.

While important for framing the analysis, the visual correlations fail to control adequately for factors influencing both inequality and social attitudes for redistribution. First, common shifts in attitudes over time (e.g., a greater worldwide concern for inequality not necessarily linked to changes in the inequalities of individual countries) can affect the results. A robust analysis should also control for changes between surveys in national income and demography (e.g., an aging population). Finally, and most importantly, social-mobility experiences and beliefs regarding the sources of success are primary determinants of attitudes toward redistribution. It is important to account for changes in these experiences and perceptions to isolate the role of increasing inequality.

To characterize how inequality changes influence social preferences, the study estimates a series of regressions with individual responses to the surveys as dependent variables. For simplicity, only least-squares specifications are discussed; ordered-logit specifications that allow for non-linearities in responses yield similar results. The primary estimation equation takes the following form (person $i$, country $c$, year $t$ ):

$$
R E S P_{i, c, t}=\phi_{c}+\eta_{t}+\beta \ln \left(G I N I_{c, t-1}\right)+\lambda N_{c, t-1}+\gamma X_{i, c, t}+\epsilon_{i, c, t},
$$

where $\phi_{c}$ and $\eta_{t}$ are vectors of country and year fixed effects, respectively. The cross-sectional effects $\phi_{c}$ control for the long-run positions of each country in terms of preferences and inequality levels, while the year effects $\eta_{t}$ control for systematic changes between surveys in inequality growth and survey responses. These panel variables focus identification on relative changes in inequality and survey responses across countries in the sample. Regressions are weighted to form nationally representative samples and to have each country-survey carry the same significance. The results are robust to different weighting strategies. Standard errors are clustered by country.

The $\beta$ coefficient is the focus of this study. Survey responses are ordered so that a positive $\beta$ coefficient reflects a more-concerned position: greater concern for inequality, more support for government intervention, and so on. The exception is the Proposed Doctor-Unskilled Worker 
Wage Ratio, where a positive $\beta$ coefficient reflects a wider proposed wage differential. The gini estimates are preferably lagged one year. The $N_{c, t-1}$ vector of covariates includes controls for macroeconomic conditions in each country contemporaneous with the inequality measure. A log GDP per capita covariate controls for national wealth at the time of the survey; two other covariates control for the share of economic activity in the country-year coming from industry/manufacturing and from services. These factors can influence preferences for redistribution independent of inequality, and incorporating these macroeconomic controls better isolates inequality's role. Finally, the $X_{i, c, t}$ vector of individual-level covariates includes personal demographics and responses to social-mobility questions as controls. These controls are discussed further below.

\subsection{International Preferences Results}

Table 2 presents the international results for the $\beta$ coefficient, with each row representing a separate set of regressions for the ISSP or WVS dependent variable indicated. To conserve space, only the observations for the Government Responsibility regressions are listed, but these counts are representative for the other ISSP estimations in Panels B-F. The first column of results is for regressions that include only country and year fixed effects and macroeconomic covariates. Variables are transformed to have a zero mean and unit standard deviation to aid in interpretation. Thus, the 0.161 coefficient on the gini estimate in the first regression for Government Responsibility indicates that a one standard-deviation growth in inequality is partially correlated with a growth of about $16 \%$ of one standard deviation in survey responses towards greater government-led redistribution.

This positive elasticity confirms the visual patterns in Panel $1 \mathrm{C}$ of Figure 1, and support for a more-progressive tax structure is also evident in Panel B. Panel G also finds a similar call for greater income equalization in the WVS sample. These partial correlations are statistically significant and of moderate economic magnitudes. Taking the United States as a specific example, the implied increase in redistribution preferences from a standard-deviation inequality growth would close the gap to the average responses of other Anglo-Saxon countries (e.g., Canada, Australia, and Great Britain), but would fall short of the levels of continental Europe and especially transition economies. The short-run responses thus reflect modest movements around the longterm levels of the countries. Nevertheless, their positive direction suggests an inequality shock alone is insufficient to start a cycle of deteriorating support for redistribution policies. ${ }^{7}$

Potential omitted variable biases are a clear concern for these first two outcomes. It is possible that the inequality metric is simply correlated with unmodeled factors that are truly responsible

\footnotetext{
${ }^{7}$ Levels regressions without country fixed effects also confirm the cross-section correlations evident in Panel $1 \mathrm{~A}$ of Figure 1. Nations with greater inequality have a significantly reduced concern for income differences, weaker support for government intervention, and lower desire for a progressive tax structure. While critical for the results, panel estimations of inequality dynamics are rarely employed (e.g., Alesina, Di Tella, and MacCulloch 2004).
} 
for the higher support for government-led redistribution. The next three rows, however, provide reassurance that concern over inequality truly underlies the support for stronger government intervention. The increase in inequality is associated with greater concern for income differences in Panel $\mathrm{C}$ and greater awareness of social conflict between poor and rich in Panel D. As a comparison, Panel E finds inequality changes are not correlated with changes in awareness of social conflict between young and old people. These outcomes are consistent with inequality growth raising concerns about disparities and prompting greater support for government redistribution.

Panel F demonstrates, however, that respondents are more likely to propose a wider wage distribution with higher inequality. A one standard-deviation growth in inequality is associated with a 0.25 standard deviation increase in proposed wage differentials. An unreported disaggregation of changes in the Proposed Doctor-Unskilled Worker Wage Ratio finds the expansion to be primarily occurring between doctors and skilled workers rather than skilled workers and unskilled workers. A similar elasticity is evident for the proposed wage differential between the chairman of a large, national company and an unskilled worker. This growth in proposed wage differentials - based upon what respondents think occupations should earn -indicates at least partial acceptance of inequality shifts due to changes in relative factor scarcities and associated rewards. The coefficient of 0.25 is statistically different from zero, a level where no support for a wider distribution is evident, and from a value of one, a level where a full endorsement of the inequality expansion is evident if the inequality increase is due to growing earnings differentials.

The 0.25 coefficient is measured using all changes in inequality, and this approach may understate the elasticity due to earnings inequality itself. By mixing growth in inequality due to labor market differentials with growth in inequality outside of the labor market, the 0.25 coefficient may underestimate the extent to which preferences regarding compensation differential expand to accommodate increases in earnings inequality. In addition to proposing wages for occupations, the ISSP surveys ask respondents what they think occupations actually earn. Fixed effect regressions of Proposed Doctor-Unskilled Worker Wage Ratio on the perceived wage ratio for doctors and unskilled workers yield elasticities of about 0.6. That is, growth in perceived inequality is again associated with larger proposed distributions, but not as wide as the perceived increase itself. This 0.6 elasticity finding, along with the reported results using national inequality changes, leads to the conclusion that social preferences over wage differentials expand to accommodate substantial portions, but not all, of growth in earnings inequality. These patterns suggest that short-run inequality shocks can be reinforced in the labor market, and that changes in compensation differentials due to changing factors of production are only modestly retarded by social preferences.

The second column of Table 2 adds each nation's log GDP per capita to capture movements in the overall wealth of the country, as well as Demographic Controls and Mobility Controls. Demographic Controls include sex, marital status, age, education, and income dummies. Mobility Controls incorporate respondents' answers to other ISSP questions that reveal beliefs and 
experiences regarding social mobility. ISSP regressions include two questions asking respondents to rate the importance of being from a wealthy family or of knowing the right people for getting ahead. Respondents believing these important significantly favor more redistribution. Past mobility experiences are also modeled by respondents' ratings of the status of their jobs compared to their fathers' jobs; respondents believing their jobs are better than their fathers' are significantly less likely to support redistribution. ${ }^{8}$

The magnitudes and significance of the $\beta$ coefficients on the gini estimates are robust to including these Demographic and Mobility Controls. Column 3 further shows the results are robust to including Work Controls of dummies for self-employed, supervisor, unemployed, and a union member. ${ }^{9}$ Coefficient elasticities are very similar after including these covariates. The coefficients in the WVS regressions continue to suggest a higher elasticity of about $35 \%$. The higher share of developing countries in the WVS sample likely plays a role in these larger partial correlations. Also, the larger estimates may be the product of offering respondents ten choices rather than five, making it easier to capture shifts in attitude. The specific wording of this question may also contribute, as further discussed in the Data Appendix.

Poorer and transitional countries tend to have higher support for redistribution than their OECD counterparts with similar levels of inequality (Austen 1999, Suhrcke 2001). Moreover, they demonstrate significant changes in attitudes and inequality levels that dwarf the morestable advanced nations. To ensure the sample composition between OECD and non-OECD countries is not driving the results, Column 4 includes Year x OECD dummies. Likewise, the fifth column incorporates Year $\mathrm{x}$ Transition Economy dummies. The point estimates of the $\beta$ coefficients typically decline when forcing the variation to be within the subgroups, but the elasticities mostly remain economically and statistically important. Kerr (2005) extends the graphical analysis in Figure 1 to also show the variations in these subgroups. ${ }^{10}$

\subsection{Extensions and Discussion of Identification}

The sample employed in Table 2 builds off of the ISSP Social Inequality module. The Government Responsibility and Progressive Taxation questions are also included in the Role of the

\footnotetext{
${ }^{8}$ The 1990 and 1995 WVS surveys asked respondents to rate whether hard work or luck determines success or failure. The reported WVS results are robust to focusing on these survey years and including this control.

${ }^{9}$ Coefficients on the Demographic and Work Controls follow the patterns found in previous cross-sectional studies (e.g., Suhrcke 2001, Alesina and La Ferrara 2005). As the quality of income data varies substantially across surveys and countries, respondents are grouped into family-income quintiles for each survey year. Support for redistribution declines with income; support also tends to be lower among male and more-educated respondents. Self-employed workers and supervisors tend to have less support for redistribution, while unemployed workers and union members are more supportive. While reasonable, the direction of these findings should be treated with caution as income variation not captured by the quintile groupings may be loading onto other demographic and work characteristics. Finally, race/minority status is not included in the demographics; later results indicate this is an important factor for the United States (e.g., Luttmer 2001, Luttmer and Singhal 2011, Fong and Luttmer 2011).

${ }^{10}$ Very similar results are obtained without the macroeconomic controls. For example, elasticities for Government Responsibility and Proposed Doctor-Unskilled Worker Wage Ratio are 0.161 (0.057) and 0.260 (0.076), respectively, when only considering inequality and country and year fixed effects.
} 
Government modules since 1985. A longer panel can be constructed that combines surveys from these two modules. While the panel enjoys more countries and higher-frequency variation in macroeconomic conditions, it unfortunately lacks the important Mobility Controls. The findings from this longer panel mirror those in Table 2. A second version of the Government Responsibility question is also included in the Role of the Government surveys and the ISSP Religion modules. Results from this third panel are also consistent with those presented in Table 2. The stability of the findings through shifting time intervals and countries surveyed speaks to the robustness of the measured short-run response in redistribution preferences.

A causal interpretation for these results is reasonable, although not assured. Two basic concerns are the endogenous relationship between inequality and preferences (i.e., that preferences also influence the inequality levels) and omitted-variable biases. The direction of the results suggests that the reverse-causality concern is weak. It is difficult to argue that changes in social preferences to favor more income equalization produced increases in inequality, while it is very reasonable that increased inequality led to greater support for redistribution. Employing disposable-income inequalities rather than gross-income inequalities may bias the coefficient magnitudes slightly, but will not change the direction of the findings. On a similar note, this study concludes that adjustments in preferences for compensation differentials allow inequality to become entrenched in the labor market. While these results have greater scope for reverse causality, the growing concern by respondents over income inequality and the greater support for government-led interventions suggest that the wider proposed wage differentials are primarily a reaction to the inequality changes, albeit one that sustains the inequality increase.

It may be possible, however, to argue an omitted factor prompted both the increases in inequality and the changes in social preferences. For example, an increased openness to trade may have raised inequality and also increased desire for government income stabilization out of fear of globalization (and unrelated to the change in inequality itself). As noted earlier, the consistent results of higher inequality being associated with greater concern over income disparities suggest, however, that the most plausible interpretation is the increased inequality acted directly on social preferences. A more-rigorous instrument strategy employed with the U.S. data will also support this interpretation. Unfortunately, the U.S. survey employed in the next section does not contain wage differential questions like the ISSP. Thus, the U.S. instruments are only able to assess causality for the general redistribution result. ${ }^{11}$

\footnotetext{
${ }^{11}$ Suggestive evidence from the international panel can be taken from an approach that instruments each country's inequality trends using the inequality trend of its closest neighbor. Second-stage elasticities for Government Responsibility and Proposed Doctor-Unskilled Worker Wage Ratio are 0.234 (0.100) and 0.198 (0.125), respectively, when using the framework in Column 1 of Table 2. The instrument, however, is weak with a first-stage coefficient of $0.615(0.336)$ and an F-statistic of 3.2 (standard errors clustered by country). This weakness and concerns over the exclusion restriction suggest cautious interpretation.
} 


\section{Preferences in U.S. Surveys}

To complement the international findings, regional variation in inequality and support for redistribution from the United States is explored next. This study is important for three reasons. First, while national inequality would be the most perceived dimension for smaller countries such as Bulgaria or Ireland, regional differences may be more important for large nations that display significant heterogeneity in economic activity. Moreover, a substantial fraction of policy and budget decisions in the United States are made at the state or city level, with officials accountable to their local constituents. Finally, but certainly not least from a research perspective, the quality and quantity of U.S. data afford extensions and instruments that are not possible in international studies.

\subsection{GSS Data Structure}

U.S. social preferences are estimated from the General Social Survey (GSS). The GSS has been conducted on an annual or biennial basis since 1972 with sample sizes ranging from 1400 to 3000 adults. The analysis considers four questions on the survey through 2000 . The first question asks on a three-point scale whether the United States should be spending more or less money on welfare (Welfare Spending); an identical question regarding spending for the space exploration program (Space Exploration Program Spending) is also considered as a falsification exercise similar to the conflict between the young and old question in the international study. A third question (GSS Income Equalization) documents respondent support on a seven-point scale for the federal government's reduction of income differences between the rich and the poor. Responses are again ordered so that higher values correspond to higher support for the reduction of inequality. ${ }^{12}$

The analysis also considers how changes in political-party affiliation correlate with changing inequality levels (Party Identification). Respondents are asked to state their party preference and the strength of this association on a seven-point scale, with one being strongly Republican and seven being strongly Democrat. Of course, many other factors influence party affiliation, and the platforms of parties demonstrate temporal and regional variation. Nevertheless, it is reasonable to portray the Democratic Party over the last three decades as supporting higher levels of redistribution from the United States' wealthy classes to its poorer classes than the Republican Party. Regressions with this question study whether higher inequality is associated with changes in political affiliation, in addition to changes in support for welfare programs. The Data Appendix details the wording of these four questions.

The final requirements for the U.S. analyses are the important inequality metrics. The rich-

\footnotetext{
${ }^{12}$ To validate these surveys, Luttmer (2001) demonstrates that over $30 \%$ of the variation in state welfare-benefit levels can be explained through an interaction of attitudes towards welfare with state demographic compositions. He also considers how norms for redistribution modeled with the GSS mirror voting patterns in a California proposition.
} 
ness of U.S. data offers additional flexibility, and two metrics of overall inequality are considered. Modeling inequality with regional log gini estimates affords comparisons to the earlier international work. The detailed data also allow consideration of inequality trends for different parts of the income distribution. Thus, overall inequality is additionally modeled as the differential between the $\log 80$ th and 20 th percentiles. After considering overall inequality, the 80-20 differential is disaggregated into the changes in inequality in the upper and lower halves of the distribution (i.e., the 80-50 and 50-20 differentials). Inequality estimates in this section are calculated over disposable family income for the four primary Census regions (i.e., Northeast, Midwest, South, and West) from the March Current Population Surveys (CPS). Robustness checks show these results are representative of other income definitions (e.g., pre-tax family labor earnings, hourly wage) and lower levels of regional aggregation (e.g., nine Census regions, states). ${ }^{13}$

Figure 2 plots the mean response to the GSS Welfare Spending question and the 80-20 income differential for each region by year. Two identification issues for the U.S. findings can be discerned from this graph. First, differences in regional inequality trends exist (the solid line). While the South begins with significantly higher inequality than the other regions in the early 1970s, the strong growth in inequality in the Northeast and West results in the three regions being approximately equal by the late 1990s. The Midwest, while also experiencing an increase in inequality, remains significantly lower than the South throughout the period. Unlike the international analysis, however, none of the regions experience a period of substantial decline in inequality. Thus the inference is from stable inequality or relative increases in inequality.

Second, the dramatic swings in the mid-1970s and 1990s highlight that regional variation in welfare support can be second-order to large national shifts, likely due to political swings. The significant decline in support in the mid-1970s is linked to the explosion in welfare caseloads in the prior decade (e.g., Moffitt, Ribar, and Wilhelm 1998), while the large dip in the mid-1990s surrounds the 1994 Republican Revolution during Clinton's first term. The close co-movement of regional inequality and Welfare Spending preferences between these periods is quite striking. The national trends in inequality and social preferences are absorbed by the year effects, while systematic levels differences between regions are controlled for by geographic fixed effects. Given

\footnotetext{
${ }^{13}$ Three levels of geographic aggregation and three forms of inequality are considered for the United States. On the geographic dimension, inequality estimates for Census regions (four or nine) are calculated from the March CPS files. These annual measures are preferred since decade-based measurements can miss important fluctuations, most noticeably the significant expansion in family-income inequality during the recessions of the early 1980s and 1990s. The sample sizes of the March CPS are insufficient, however, for state-level analyses and states are not identified until 1977. State-level statistics are instead calculated from the Census for each decade.

Three income definitions are considered: post-tax disposable family income from all sources, pre-tax family labor earnings, and hourly wages. The first two family measures are calculated over family equivalents using Danziger and Gottschalk's (1995) procedure of dividing by an inflation-adjusted poverty-line estimate for a family of similar composition (i.e., the number and ages of adults and children in the family unit). Additional procedures for preparing the sample (e.g., the exclusion of military families, adjustment of top-codes) follow Danziger and Gottschalk (1995), Autor, Katz, and Krueger (1998), and Katz and Autor (1999).

In each analysis, the region fixed effects and median income levels are adjusted to the appropriate geographic aggregation; median income levels are additionally adjusted to reflect the income definition used in the inequality calculation. The Data Appendix reports the regional disposable-income 80-20 differential estimates employed in the primary regressions.
} 
the importance of these national elements, the regression coefficients for the regional variation may be smaller than those captured in the international estimations. ${ }^{14}$

\subsection{U.S. Preferences Results}

Table 3A considers a set of specifications similar to the international regressions studied in Table 2; Table 3B replaces the log gini inequality metrics with log 80-20 income differentials. Standard errors are bootstrapped for the U.S. analysis. ${ }^{15}$ Column 1 of both specifications finds changes in regional inequality partially correlate with a statistically significant increase in support for all three preferences when only year and region fixed effects are included. As expected, the coefficients are somewhat smaller than those found in the international regressions, as the regional variation is weaker than national trends. As a falsification exercise for Welfare Spending, if anything respondents urge a decline in Space Exploration Program Spending when inequality increases, but this result is not precisely measured.

As before, Columns 2 and 3 further show the magnitudes and statistical significance of the coefficients are robust to including the regional median income (akin to the national GDP per capita) and Demographic Controls, Mobility Controls, and Work Controls. Unfortunately, incorporating many GSS social-mobility variables severely limits the sample size; the regressions only include a question that asks whether the financial position of a respondent's family has improved, worsened, or stayed the same over the last few years. The GSS does, however, collect race data. Non-white respondents are found in the fourth column to have significantly higher support for redistribution, even after including income levels and the other Demographic Controls. The coefficients for Welfare Spending and Party Identification remain of similar size and significance, but those for Income Equalization diminish. These results are robust to excluding the South from the analysis. ${ }^{16,17}$

\subsection{Empirical Extensions}

A significant concern about the analysis thus far is that gini estimates only measure overall inequality. A detailed exploration should further identify the subsets of the income distribution that are most important for changes in social preferences. While more-disaggregated international statistics are very rare and typically of poor quality, U.S. data are available. Table 4

\footnotetext{
${ }^{14}$ While representative, the mean regional responses should be treated with caution. The sampling design of the GSS results in certain states or metropolitan areas with distinct differences in social preferences from their surrounding region entering and leaving the survey (e.g., the more-religious Utah in the West). While the regression results control for these shifts, the regional mean responses do not.

${ }^{15}$ The ISSP and WVS have sample weights that prohibit bootstrapping. Estimations that exclude the sample weights and bootstrap confirm Table 2's findings, with the results stronger and more precisely estimated.

${ }^{16}$ Demographic surveys often find respondents over-estimate their relative financial position. In addition to actual incomes, the GSS collects respondents' perceptions of their incomes compared to the national average. The results are robust to using these perceptions rather than actual income levels.

${ }^{17}$ Increases in inequality are also associated with shifts in party identification to the left in the ISSP and WVS samples. These results are not emphasized due to the lack of party comparability across countries compared to the U.S. analysis. There is also intriguing evidence of declines in political participation as inequality increases.
} 
decomposes the 80-20 inequality into the 80-50 and 50-20 differentials. The results suggest that trends in inequality in the lower half of the distribution (i.e., the poor being increasingly left behind) are most responsible for the aggregate results previously identified for the United States. Using 90-50 and 50-10 trends, which demonstrate less co-movement than the 80-50 and 50-20 series, yields significant results for the 50-10 ratio in all regressions (including Income Equalization). ${ }^{18}$

Two additional extensions reported in Kerr (2005) consider whether the average increase in support for redistribution with rising inequality masks differences among income classes. While the demographic characteristics of respondents are statistically significant for explaining survey answers, Piketty (1996a,b, 1999a) notes the overall level of disagreement within a country about distributive equality is usually small vis-à-vis other social issues (e.g., death penalty). Section 2 found, however, that perceptions of conflict between the poor and the rich increase with rising inequality, and it is important to clarify if the average response belies increasing disagreement among classes about appropriate redistribution levels. The rich may become more protective of their wealth as the gap grows, perhaps out of concern over larger transfers or perhaps out of reduced fear that they too may one day be poor. Altruistic motives, however, may yield greater assistance from the wealthy as disparity widens.

A first test for this heterogeneity interacts the inequality measures with whether respondents are in the top-two income quintiles or the bottom-two income quintiles. These estimations do not find significant differences by class for the GSS Welfare Spending or Income Equalization variables. Similar null results for income-quintile interactions are also present in the ISSP and WVS. Concern over rising inequality grows in all income groups (while the overall levels are higher in poor households). GSS respondents in the bottom-two quintiles are disproportionately more likely to align themselves with the Democratic Party as inequalities in their regions increase. This result, however, is sensitive to more structured controls like interacting a time trend with being in the upper-two or lower-two income quintiles, suggesting that other factors may be playing a role. ${ }^{19}$

A second test interacts the inequality measures with whether the respondent lives near someone of the opposite race. Luttmer (2001) finds support for welfare spending increases as the share of local recipients from a respondent's racial group rises. Lind (2007) also finds aggregate evidence that inequality between racial groups versus inequality within racial groups can have opposite effects for redistribution outcomes. The interacted coefficient for the Welfare Spending

\footnotetext{
${ }^{18}$ Moffitt, Ribar, and Wilhelm (1998) find evidence that declining welfare-benefit levels can be linked to declining low-skill wages, as voters seek to maintain a target benefit-wage ratio (perhaps to preserve equity between working and non-working poor or to minimize employment disincentives). The disaggregated income inequality results - in particular, the positive and significant coefficient on the 50-20 ratio - are robust to including measures of the 15 th or 25 th percentile wages.

${ }^{19}$ McCarty, Poole, and Rosenthal (2003) note increases in U.S. inequality have moved in tandem with stronger ideological differences over redistribution and more-polarized party politics. While income has become a stronger predictor of party affiliation over the last twenty-five years, their work also suggests inequality bears limited responsibility for the polarization.
} 
regression agrees with these studies - the increase in redistribution support associated with rising inequality is diminished in racially heterogeneous neighborhoods. There is no clear effect for the Income Equalization measure.

These results suggest changes in support for government-led redistribution are fairly uniform across income groups. This finding is in agreement with Rawlsian models like Piketty (1995), where different classes have similar views on distributive equality holding fixed beliefs about incentive costs. On the other hand, the standard median-voter model (e.g., Meltzer and Richard 1981) suggests increases in inequality lead to a divergence in preferences for redistribution as gaps to the median income widen. A limitation to these findings, however, is important to note. Piketty and Saez (2003) find a tremendous increase in the concentration of wealth among the very rich in the United States (i.e., the top $1 \%$ and even smaller fractions). Atkinson, Piketty, and Saez (2011) review the work that has followed regarding top income shares. Unfortunately, the data cannot be used for an analysis for these super-wealthy individuals, executive compensation committees, and similar institutions.

\section{U.S. Minimum-Wage Instrument}

U.S. regional estimations agree with the earlier international results: increases in inequality partially correlate with increases in desire for government-led redistribution. In addition to finding this effect on two levels, it was earlier noted that the direction of the results, the lagging of inequality, and the significance of survey questions focused on inequality itself suggest a causal interpretation is reasonable, although still not assured. In this section, an instrument designed for the U.S. regional variation further undergirds this claim.

In recent empirical studies, labor economists note the role of the minimum wage in rising U.S. inequality, especially during the 1979-1989 period when the real (i.e., inflation-adjusted) value of the federal rate declined by $24 \% .^{20}$ While these substantial swings in mandated federal rates can be taken as exogenous from the perspective of individual states or regions, they do not provide the necessary regional variation by themselves. An appropriate instrument can be designed, however, through the interaction of these national trends with predetermined regional characteristics that govern how important minimum-wage mandates are for the local economy. The year effects absorb the national dynamics of the changing federal rate, and the pre-existing regional traits are controlled for by the geographic fixed effects. The identifying assumption is that the residual region-year interactions can serve as an instrument for the region-year inequality trends (which are themselves also subject to the fixed effects).

This study employs regional coverage ratios, defined as the percent of the working population protected by the minimum-wage statutes, as the interaction terms. Regions differ in the

\footnotetext{
${ }^{20}$ For example, Card and Krueger (1995); DiNardo, Fortin, and Lemieux (1996); Lee (1999); Golan, Perloff, and Wu (2001a,b); Card and DiNardo (2002); Autor, Manning, and Smith (2010); and Ahn, Arcidiacono, and Wessels (2011).
} 
composition of their economic activity, and the federal minimum-wage mandates are not applied equally to industries (e.g., 1970-2000 coverage rates in agriculture averaged $41 \%$ versus manufacturing's 97\%). The larger the fraction of a region's population covered by the federal statutes, the more impact federal rates have on the local economy. The simplest interaction term would be the 1970 coverage rate; in a slight design improvement, the interaction term is built instead as the expected coverage in year $t$ for each region. This modification allows incorporation of trends in national coverage rates due to changing federal legislation (especially in the mid 1970s), thereby raising the quality of the first-stage estimations. The inequality instrument for region $r$ and year $t$ takes the form

$$
I N E Q-I V_{r, t}=\ln \left(F E D_{1970} / F E D_{t}\right) \cdot E_{1970} C O V_{r, t},
$$

where

$$
E_{1970} C O V_{r, t}=1-\sum_{j} I N D \%_{j, r, 1970} \cdot\left(C O V_{j, 1970} / C O V_{j, t}\right)
$$

with $j$ indexing industries. The two parts of this interaction deserve careful explanation. The construction of the second element, $E_{1970} C O V_{r, t}$, is the more complicated. It is the expected coverage rate in region $r$ for year $t$, estimated from the 1970 industrial composition of the working poor and changes in national coverage rates by industry. IND\% ${ }_{j, r, 1970}$ is the percent of a region's workforce from the 1970 Census who are both earning less than the minimum wage and working in industry $j$. By itself, $\sum_{j} I N D \%_{j, r, 1970}$ would produce the actual percentage of the region's working population earning less than the federal minimum wage in 1970 . $C O V_{j, 1970} / C O V_{j, t}$ is the ratio of the national coverage rate for industry $j$ in 1970 to that in year $t$. From a starting value of one, the ratio moves above one for industries where the coverage rates decrease compared to 1970 levels; it moves below one when coverage rates increase. ${ }^{21}$

The combination of these terms is the expected percentage of a region's workforce earning below the minimum wage in year $t$. The starting 1970 level of $\sum_{j} I N D \%_{j, r, 1970} \cdot\left(C O V_{j, 1970} / C O V_{j, t}\right)$ is still the actual workforce percentage earning below the 1970 federal rate in each region (as the coverage ratio for all industries is one). For subsequent years, it is expected that the percentage of the population earning below the minimum wage will decline in region $r$ if its poor workers were primarily employed in industries where the coverage rate later increased. On the other hand, little change is expected in states or regions where very few workers were initially below the minimum wage or where the poor worked in industries for which the coverage rate did not change significantly. Finally, $1-\sum_{j} I N D \%_{j, r, 1970} \cdot\left(C O V_{j, 1970} / C O V_{j, t}\right)$ estimates the percent of the population covered by the minimum-wage mandates and thus the potential importance of changes in the federal rate for the region's inequality level.

\footnotetext{
${ }^{21}$ Coverage rates are at the one-digit SIC level and exclude government employees (e.g., Nordlund 1997, United States Department of Labor 1998). Coverage rates have not been identified for 1989 or after 1996 . For the main estimations, a linear interpolation is employed for 1989 and observations post-1997 are assigned 1996 values; the results are robust to dropping these missing years. Unfortunately, the coverage data are not disaggregated to where each observation's own region could be excluded. As the Data Appendix shows, the expected coverage rate calculations produce only a slight trend vis-à-vis fixed 1970 levels.
} 
Turning to the first term, $\ln \left(F E D_{1970} / F E D_{t}\right)$, the $\log$ ratio of the real federal minimumwage rate in 1970 to the rate in year $t$ takes an initial value at zero for 1970. In years when the real federal rate is greater than the real federal rate for 1970, this component of the instrument has a negative value, and vice versa. Note that some states have mandated minimum wages that exceed the federal rate. These are not considered as the local legislation could clearly be endogenous to the inequality levels. The Data Appendix provides descriptive statistics for these two components of the instrument.

The instrument is then the interaction of shifts in the real federal rate with the expected coverage level, or how much the federal legislation matters for a region. The instrument comes only from the interaction between these two elements. The individual trends of the real federal rate and industry coverage rates are absorbed by the year effects. Geographic fixed effects control for the region's predetermined industrial composition of poor workers. The instrument does not have a level per se-its value for all regions is zero when the real federal rate is equal to its 1970 level (i.e., 1970 itself, approximately so in 1975, 1976 and 1981). It relies on the region fixed effects to control for the mean inequality positions of each area. Finally, the instrument is designed to have a positive first-stage coefficient. The $E_{1970} C O V_{r, t}$ term is always positive and only governs the magnitude of the response; the $\ln \left(F E D_{1970} / F E D_{t}\right)$ component is positive when the current federal rate is below its 1970 level, which should correspond to rising inequality, and vice versa.

Figure 3 plots a graphical version of the first stage for each region. The lines for the minimumwage instrument (the solid line) and the inequality level (the line with circles) are residuals after year and geographic fixed effects are removed. The expected first-stage relationship is apparent within each region. Estimated at the regional level and using bootstrapped standard errors, the first-stage coefficient for regional gini inequality is $1.50(0.40)$, with an F statistic of 11.7 and a partial $R^{2}$ of 0.16 . The first-stage coefficient for the regional $\log 80-20$ differential is $1.53(0.53)$, with an F statistic of 7.3 and a partial $R^{2}$ of 0.10 .

Tables $5 \mathrm{~A}$ and $5 \mathrm{~B}$ present the detailed results of the instrumental-variable specifications for the $\log$ gini and 80-20 differentials, respectively. As inequality is lagged one year in the estimations, the instrument is lagged as well. The second-stage results confirm the least-square specifications discussed earlier; a one standard-deviation increase in inequality is now found to produce $20 \%$ of a standard-deviation shift in support for government-led redistribution and political party identification. Substantially weaker results are found on the other two variables. The instrument specifications are robust to using other forms of aggregate inequality (90-10 differentials, entropy) or focusing on the lower half of the income distribution through 50-20 differentials. The small increase in coefficient magnitude from the least squares results is likely due to the instrument focusing on inequality in the lower part of the income distribution.

Table 6 concludes by replicating the Column 2 regressions of Tables 3A and 5A (i.e., estimations including median income levels, Demographic Controls, and Mobility Controls) across 
three levels of geographic aggregation and three income definitions. The first three columns are for least-squares regressions, while the last three columns are for instrumental-variable specifications. The two regional specifications are annual and derived from the March CPS while the state specifications are at the decade level and derived from the Census. The least-squares permutations are well-behaved and generally indicate a moderate decline in coefficient size as specifications move away from disposable family income towards the hourly wage definition. The declining coefficient sizes with lower levels of geographic aggregation mirror the earlier coefficient reduction from the international regressions to the four Census regions variation. However, these two trends are weaker in the instrumental-variable permutations. While larger standard errors are evident in some state-level or hourly wage specifications, the instrumental-variable results in general are robust across these dimensions. The Data Appendix describes further robustness checks made on the instrument's design.

\section{Conclusions}

This study characterizes how changes in inequality affect social attitudes towards government-led redistribution and compensation differentials. Market-based factors have substantially increased inequality in the United States over the last three decades. If the inequality caused by these mechanisms reduces social preferences regarding distributive equality, the inequality can become amplified and entrenched. While international and U.S. regional cross-sections often display a strong, negative correlation between inequality and support for redistribution, this study finds countries and states do not evolve along this pattern in the short-run.

Controlling for initial positions and respondent views of social mobility, local changes in inequality are positively and significantly correlated with changes in support for government-led redistribution. While greater class conflict is perceived along income dimensions, the increases in support for redistribution among wealthy individuals are as strong as those of poorer individuals. To the extent the forces driving inequality also alter the underlying beliefs (e.g., determinants of success, mobility experiences, incentive costs) most important for determining the long-term trade-off between inequality and redistribution preferences, then these forces may contribute to reduced concern over the disparity. But the results of this study suggest that a short-term increase in inequality is unlikely to prompt a vicious cycle where support for redistribution declines, thereby promoting further increase in inequality.

On the other hand, significant growth in proposed wage differentials are evident in the international analyses with higher inequality. While less than one-for-one, increases in inequality are associated with greater acceptance of wage disparities. This pattern suggests that labor market changes may reinforce inequality growth.

Several important areas for future research exist. Political economists have long studied reasons for the negative cross-sectional relationship between inequality and support for redis- 
tribution; this study explored localized movements around these long-run positions. Recent theoretical research considers endogenous shifts in long-term positions (e.g., Benabou 2002, Hassler et. al. 2003); as more data become available, future research should empirically test these longer-term dynamics. Such shifts will further clarify the primal factors behind cross-sectional differences, highlight whether the concerned responses noted here are governed by important thresholds or critical-mass points, and identify mechanisms beyond ideology that can contribute to the formation of vicious cycles.

It is also important to characterize the channels through which inequality and preferences interact. For instance, increasing social stratification ${ }^{22}$ may amplify or diminish the direct effect of increasing inequality on social preferences. Alesina and La Ferrara (2000) report greater inequality is particularly correlated with reduced membership in church and service groups, activities often associated with assisting the less fortunate. Watson (2009) links inequality with greater income segregation in cities. This deterioration of civic bonds may weaken support for redistribution. On the other hand, Luttmer (2001) argues free-rider concerns likely reduce support for welfare policies, and perhaps these concerns are weakened in more-segmented communities. It is also unclear how the non-pecuniary status desires that can limit support for redistribution change in a more-stratified society (e.g., Corneo and Gruner 2000, 2002). A better understanding of how stratification and other channels facilitate the interaction of inequality and preferences will afford more-causal assessments and aid in policy recommendations.

Finally, and most importantly, future research should trace out how changes in social preferences translate into policy outcomes. Existing studies examining the connection of increases in inequality to policy changes related to redistribution find mixed results. ${ }^{23}$ The findings of this paper suggest that social preferences regarding inequality adjust to desire more redistribution while allowing greater labor market inequality. Different political systems - including such diverse issues as government structure, campaign financing laws, voter participation, etc.-will influence whether shifts in preferences produce important policy changes or not. The importance of franchising groups favoring higher redistribution and the disproportionate influence of elites are often noted in particular. ${ }^{24}$ How political systems are structured will govern whether rising latent concerns for redistribution produce higher effective support to which politicians are held accountable.

\footnotetext{
${ }^{22}$ For example, Putnam (2000); Benabou (1993, 1996); and Bertrand, Luttmer, and Mullainathan (2000).

${ }^{23}$ Recent examples include Rodriguez (1999); Piketty (1999b); Caminada and Goudswaard (2001); Hassler et. al. (2003); Gundersen and Ziliak (2004); Chernick (2005); Schwabish, Smeeding, and Osberg (2006); Leigh (2008); Schwabish (2008); Boustan et al. (2010); Corcoran and Evans (2010); and Cooper, Lutz, and Palumbo (2011).

${ }^{24}$ For example, Husted and Kenny (1997); Lott and Kenny (1999); and Saint-Paul (2001).
} 


\section{References}

[1] Acemoglu, Daron, "Technical Change, Inequality and the Labor Market", Journal of Economic Literature, 40:1 (2002), 7-72.

[2] Acemoglu, Daron, Phillipe Aghion, and Giovanni Violante, "Deunionization, Technical Change and Inequality", Carnegie-Rochester Conference Series on Public Policy (2001).

[3] Acemoglu, Daron, and David Autor, "Skills, Tasks and Technologies: Implications for Employment and Earnings", in Ashenfelter, Orley, and David Card (eds.) Handbook of Labor Economics Volume 4 (Amsterdam: Elsevier, 2011).

[4] Ahn, Tom, Peter Arcidiacono, and Walter Wessels, "The Distributional Impacts of Minimum Wage Increases when Both Labor Supply and Labor Demand are Endogenous", Journal of Business and Economic Statistics, 29:1 (2011), 12-23.

[5] Alesina, Alberto, and George-Marios Angeletos, "Fairness and Redistribution", American Economic Review, 95:4 (2005), 960-980.

[6] Alesina, Alberto, Rafael Di Tella, and Robert MacCulloch, "Inequality and Happiness: Are Europeans and Americans Different?", Journal of Public Economics, 88 (2004), 2009-2042.

[7] Alesina, Alberto, Edward Glaeser, and Bruce Sacerdote, "Why Doesn't the United States Have a European-Style Welfare State?", Brookings Papers on Economic Activity, 2001:2 (2001), 187-277.

[8] Alesina, Alberto, and Eliana La Ferrara, "Participation in Heterogeneous Communities", Quarterly Journal of Economics, 115:3 (2000), 847-904.

[9] Alesina, Alberto, and Eliana La Ferrara, "Preferences for Redistribution in the Land of Opportunities", Journal of Public Economics, 89 (2005), 897-931.

[10] Atkinson, Anthony, "The Changing Distribution of Income: Evidence and Explanations", German Economic Review, 1:1 (2000), 3-18.

[11] Atkinson, Anthony, and Andrea Brandolini, "Promise and Pitfalls in the Use of Secondary Data-Sets: Income Inequality in OECD Countries as a Case Study", Journal of Economic Literature, 34:3 (2001), 771-799.

[12] Atkinson, Anthony, Thomas Piketty, and Emmanuel Saez, "Top Incomes in the Long Run of History", Journal of Economic Literature, 49:1 (2011), 3-71.

[13] Austen, Sioghan, "Norms of Inequality", Journal of Economic Issues, 33:2 (1999), 435-442.

[14] Autor, David, and David Dorn, "The Growth of Low-Skill Service Jobs and the Polarization of the U.S. Labor Market", NBER Working Paper (2011).

[15] Autor, David, Lawrence Katz, and Melissa Kearney, "Trends in U.S. Wage Inequality: Revising the Revisionists", Review of Economics and Statistics, 90:2 (2008), 300-323.

[16] Autor, David, Lawrence Katz, and Alan Krueger, "Computing Inequality: Have Computers Changed the Labor Market?", Quarterly Journal of Economics, 113:4 (1998), 1169-1213. 
[17] Autor, David, Alan Manning, and Christopher Smith, "The Contribution of the Minimum Wage to U.S. Wage Inequality over Three Decades: A Reassessment", NBER Working Paper 16533 (2010).

[18] Benabou, Roland, "Workings of a City: Location, Education, and Production", Quarterly Journal of Economics, 108:3 (1993), 619-652.

[19] Benabou, Roland, "Heterogeneity, Stratification, and Growth: Macroeconomic Implications of Community Structure and School Finance", American Economic Review, 86:3 (1996), 584-609.

[20] Benabou, Roland, "Inequality and Growth", in Bernanke, Benjamin, and Julio Rotemberg (eds.) NBER Macroeconomic Annual, 1996, 11-74.

[21] Benabou, Roland, "Unequal Societies: Income Distribution and the Social Contract", American Economic Review, 90:1 (2000), 96-129.

[22] Benabou, Roland, "Human Capital, Technical Change, and the Welfare State", Working Paper (2002).

[23] Benabou, Roland, and Efe Ok, "Social Mobility and the Demand for Redistribution: The POUM Hypothesis", Quarterly Journal of Economics, 116:2 (2001), 447-487.

[24] Benabou, Roland, and Jean Tirole, "Belief in a Just World and Redistributive Politics", Quarterly Journal of Economics, 121:2 (2006), 699-746.

[25] Berman, Eli, John Bound, and Zvi Griliches, "Changes in the Demand for Skilled Labor Within U.S. Manufacturing: Evidence from the Annual Survey of Manufacturers", Quarterly Journal of Economics, 109 (1994), 367-397.

[26] Bertrand, Marianne, Erzo Luttmer, and Sendhil Mullainathan, "Network Effects and Welfare Culture", Quarterly Journal of Economics, 115:4 (2000), 1019-1055.

[27] Bok, Derek, The Cost of Talent: How Executives and Professionals Are Paid and How It Affects America (New York, N.Y.: Free Press, 1993).

[28] Buchinsky, Moshe, and Jennifer Hunt, "Wage Mobility in the United States", Review of Economics and Statistics, 81:3 (1999), 351-368.

[29] Boustan, Leah Platt, Fernando Ferreira, Hernan Winkler, and Eric Zolt, "Income Inequality and Local Government in the United States, 1970-2000", NBER Working Paper 16299 (2010).

[30] Caminada, Koen, and Kees Goudswaard, "International Trends in Income Inequality and Social Policy", International Tax and Public Finance, 8 (2001), 395-415.

[31] Card, David, and Alan Krueger, Myth and Measurement (Princeton, N.J.: Princeton University Press, 1995).

[32] Card, David, "The Effect of Unions on Wage Inequality in the U.S. Labor Market", Industrial and Labor Relations Review, 54:2 (2001), 296-315.

[33] Card, David, and John DiNardo, "Skill-Biased Technological Change and Rising Wage Inequality: Some Problems and Puzzles", Journal of Labor Economics, 20:4 (2002), 733783. 
[34] Card, David, and Thomas Lemieux, "Can Falling Supply Explain the Rising Return to College for Younger Men? A Cohort-Based Analysis", Quarterly Journal of Economics, 116:2 (2001), 705-746.

[35] Card, David, Thomas Lemieux, and Craig Riddell, "Unions and Wage Inequality", Journal of Labor Research, 25 (2004).

[36] Chernick, Howard, "On the Determinants of Subnational Tax Progressivity in the U.S.", National Tax Journal, 58 (2005), 93-112.

[37] Clark, Andrew, "Unemployment as a Social Norm: Psychological Evidence from Panel Data", Journal of Labor Economics, $21: 2$ (2003), 323-351.

[38] Cooper, Daniel, Byron Lutz, and Michael Palumbo, "The Role of Federal and State Taxes in Mitigating Wage Inequality", Working Paper (2011).

[39] Corcoran, Sean, and William Evans, "Income Inequality, the Median Voter, and the Support for Public Education", NBER Working Paper 16097 (2010).

[40] Corneo, Giacomo, and Hans Peter Gruner, "Individual Preferences for Political Redistribution", Journal of Public Economics, 83 (2002), 81-107.

[41] Corneo, Giacomo, and Hans Peter Gruner, "Social Limits to Redistribution", American Economic Review, 90:5 (2000), 1491-1507.

[42] Danziger, Sheldon, and Peter Gottschalk, America Unequal (Cambridge, M.A.: Harvard University Press, 1995).

[43] Deininger, Klaus, and Lyn Squire, "A New Data Set Measuring Income Inequality", World Bank Economic Review, 10:3 (1996), 565-592.

[44] DiNardo, John, Nicole Fortin, and Thomas Lemieux, "Labor Market Institutions and the Distribution of Wages, 1973-1992: A Semiparametric Approach", Econometrica, 64:5 (1996), 1001-1044.

[45] Fong, Christina, "Social Preferences, Self-Interest, and the Demand for Redistribution", Journal of Public Economics, 82 (2001), 225-246.

[46] Fong, Christina, "Prospective Mobility, Fairness, and the Demand for Redistribution", Working Paper (2006).

[47] Fong, Christina, and Erzo Luttmer, "Do Race and Fairness Matter in Generosity? Evidence from a Nationally Representative Charity Experiment", Journal of Public Economics, 95:5-6 (2011), 372-394.

[48] Frank, Robert, and Philip Cook, The Winner-Take-All Society (New York, N.Y.: Free Press, 1995).

[49] Glaeser, Edward, "Inequality", in Barry Weingast and Donald Wittman (eds.) The Oxford Handbook of Political Economy (New York, N.Y.: Oxford University Press, 2006).

[50] Golan, Amos, Jeffrey Perloff, and Ximing Wu, "Welfare Effects of Minimum Wages and Other Government Policies", Working Paper (2001a). 
[51] Golan, Amos, Jeffrey Perloff, and Ximing Wu, "Effects of Government Policies on Income Distribution and Welfare", Working Paper (2001b).

[52] Gordon, Robert, and Ian Dew-Becker, "Controversies about the Rise of American Inequality: A Survey", NBER Working Paper 13982 (2008).

[53] Gottschalk, Peter, and Timothy Smeeding, "Cross-National Comparisons of Earnings and Income Inequality", Journal of Economic Literature, 35:2 (1997), 633-687.

[54] Gottschalk, Peter, and Timothy Smeeding, "Empirical Evidence on Income Inequality in Industrialized Countries", in Atkinson, Anthony, and Francois Bourguignon, ed., Handbook of Income Distribution, Volume 1 (Elsevier North-Holland Pergamon, 2000), 261-307.

[55] Guadalupe, Maria, "Product Market Competition, Returns to Skill, and Wage Inequality", Journal of Labor Economics, 25:3 (2007), 439-474.

[56] Gundersen, Craig, and James Ziliak, "Poverty and Macroeconomic Performance Across Space, Race, and Family Structure", Demography, 41:1 (2004), 61-86.

[57] Guvenen, Fatih, Burhanettin Kuruscu, and Serdar Ozkan, "Taxation of Human Capital and Wage Inequality: A Cross-Country Analysis", NBER Working Paper 15526 (2011).

[58] Hassler, John, Jose Rodriguez, Kjetil Storesletten, and Fabrizio Zilibotti, "The Survival of the Welfare State", American Economic Review, 93:1 (2003), 87-112.

[59] Heathcote, Jonathan, Fabrizio Perri, and Giovanni Violante, "Unequal We Stand: An Empirical Analysis of Economic Inequality in the United States: 1967-2006", Review of Economic Dynamics, 13:1 (2010), 15-51.

[60] Husted, Thomas, and Lawrence Kenny, "The Effect of the Expansion of the Voting Franchise on the Size of Government", Journal of Political Economy, 105:1 (1997), 54-82.

[61] Katz, Lawrence, and David Autor, "Changes in the Wage Structure and Earnings Inequality", in Ashenfelter, Orley, and David Card, ed., Handbook of Labor Economics, Volume 3 (Elsevier North-Holland Pergamon, 1999), 1463-1555.

[62] Katz, Lawrence, and Kevin Murphy, "Changes in Relative Wages, 1963-1987: Supply and Demand Factors", Quarterly Journal of Economics, 107 (1995), 35-78.

[63] Kerr, William, "Income Inequality and Social Norms for Compensation Differentials and Government-Led Redistribution", Chapter 4, MIT Economics Ph.D. Dissertation (2005).

[64] Kremer, Michael, and Eric Maskin, "Wage Inequality and Segregation By Skill", NBER Working Paper 5718 (1996).

[65] Krusell, Per, Lee Ohanian, Jose-Victor Rios-Rull, and Giovanni Violante, "Capital-Skill Complementarity and Inequality: A Macroeconomic Analysis", Econometrica, 68:5 (2000), 1029-1053.

[66] Lee, David, "Wage Inequality in the United States During the 1980s: Rising Dispersion or Falling Minimum Wage?", Quarterly Journal of Economics, 114:3 (1999), 977-1023.

[67] Leigh, Andrew, "Do Redistributive State Taxes Reduce Inequality?", National Tax Journal, 61:1 (2008), 81-104. 
[68] Lemieux, Thomas, "The Changing Nature of Wage Inequality", Journal of Population Economics, 21:1 (2008), 21-48.

[69] Lind, Jo Thori, "Fractionalization and the Size of Government", Journal of Public Economics 91 (2007), 51-76.

[70] Lott, John, and Lawrence Kenny, "Did Women's Suffrage Change the Size and Scope of Government?", Journal of Political Economy, 107:6 (1999), 1163-1198.

[71] Luttmer, Erzo, "Group Loyalty and the Taste for Redistribution", Journal of Political Economy, 109:3 (2001), 500-528.

[72] Luttmer, Erzo, and Monica Singhal, "Culture, Context, and the Taste for Redistribution", American Economic Journal: Economic Policy, 3:1 (2011), 157-179.

[73] McCarty, Nolan, Keith Poole, and Howard Rosenthal, "Political Polarization and Income Inequality", Working Paper (2003).

[74] Meltzer, Allan, and Scott Richards, "A Rational Theory of the Size of Government", Journal of Political Economy, 89:5 (1981), 914-927.

[75] Moffitt, Robert, David Ribar, and Mark Wilhelm, "The Decline of Welfare Benefits in the U.S.: The Role of Wage Inequality", Journal of Public Economics, 68 (1998), 421-452.

[76] Nordlund, William, The Quest for a Living Wage: The History of the Federal Minimum Wage Program (Westport, C.T.: Greenwood Press, 1997).

[77] Piketty, Thomas, "Social Mobility and Redistributive Politics", Quarterly Journal of Economics, 110:3 (1995), 551-584.

[78] Piketty, Thomas, "The Politics of Redistribution: Recent Developments and Research Perspectives", McArthur Foundation Costs of Inequality Project meeting presentation (1996a).

[79] Piketty, Thomas, "Mobilite Economique et Attitudes Politiques Face a la Redistribution", CEPRE Working Paper 9603 (1996b).

[80] Piketty, Thomas, "Attitudes Toward Income Inequality in France: Do People Really Disagree?", CEPRE Working Paper 9918 (1999a).

[81] Piketty, Thomas, "Can Fiscal Redistribution undo Skill-Biased Technical Progress? Evidence from the French Experience", European Economic Review, 43:4-6 (1999b), 839-851.

[82] Piketty, Thomas, and Emmanuel Saez, "Income Inequality in the United States, 1913-1998", Quarterly Journal of Economics, 118:1 (2003), 1-39.

[83] Putnam, Robert, Bowling Alone: The Collapse and Revival of American Community (New York, N.Y.: Touchstone 2000).

[84] Rodriguez, Francisco, "Does Distributional Skewness lead to Redistribution?: Evidence from the United States", Economics and Politics, 11:2 (1999), 171-199.

[85] Rosen, Sherwin, "The Economics of Superstars", American Economic Review, 71:5 (1981), 845-858. 
[86] Rotemberg, Julio, "Perceptions of Equity and the Distribution of Income", Journal of Labor Economics, 20:2 (2002), 249-288.

[87] Saint-Paul, Gilles, "The Dynamics of Exclusion and Fiscal Conservatism", Review of Economic Dynamics, 4 (2001), 275-302.

[88] Schwabish, Jonathan, "The Effects of Earnings Inequality on State Social Spending in the United States", Public Finance Review, 36:5 (2008), 588-613.

[89] Schwabish, Jonathan, Timothy Smeeding, and Lars Osberg, "Income Distribution and Social Expenditures: A Cross-National Perspective", in Dmitri Papadimitriou (ed.) The Distributional Effects of Government Spending and Taxation (Northampton, MA: Edward Elgar Publishing, 2006).

[90] Suhrcke, Marc, "Preferences for Inequality: East vs. West", HWWA Discussion Paper 150 (2001).

[91] United States Department of Labor, Employment Standards Administration, Minimum Wage and Overtime Hours Under the Fair Labor Standards Act (Washington, D.C.: Government Printing Office, 1998).

[92] Watson, Tara, "Inequality and the Measurement of Residential Segregation by Income in American Neighborhoods", Review of Income and Wealth, 55:3 (2009), 820-844. 


\section{Fig. 1: Social Preferences Regarding Inequality in ISSP Surveys}
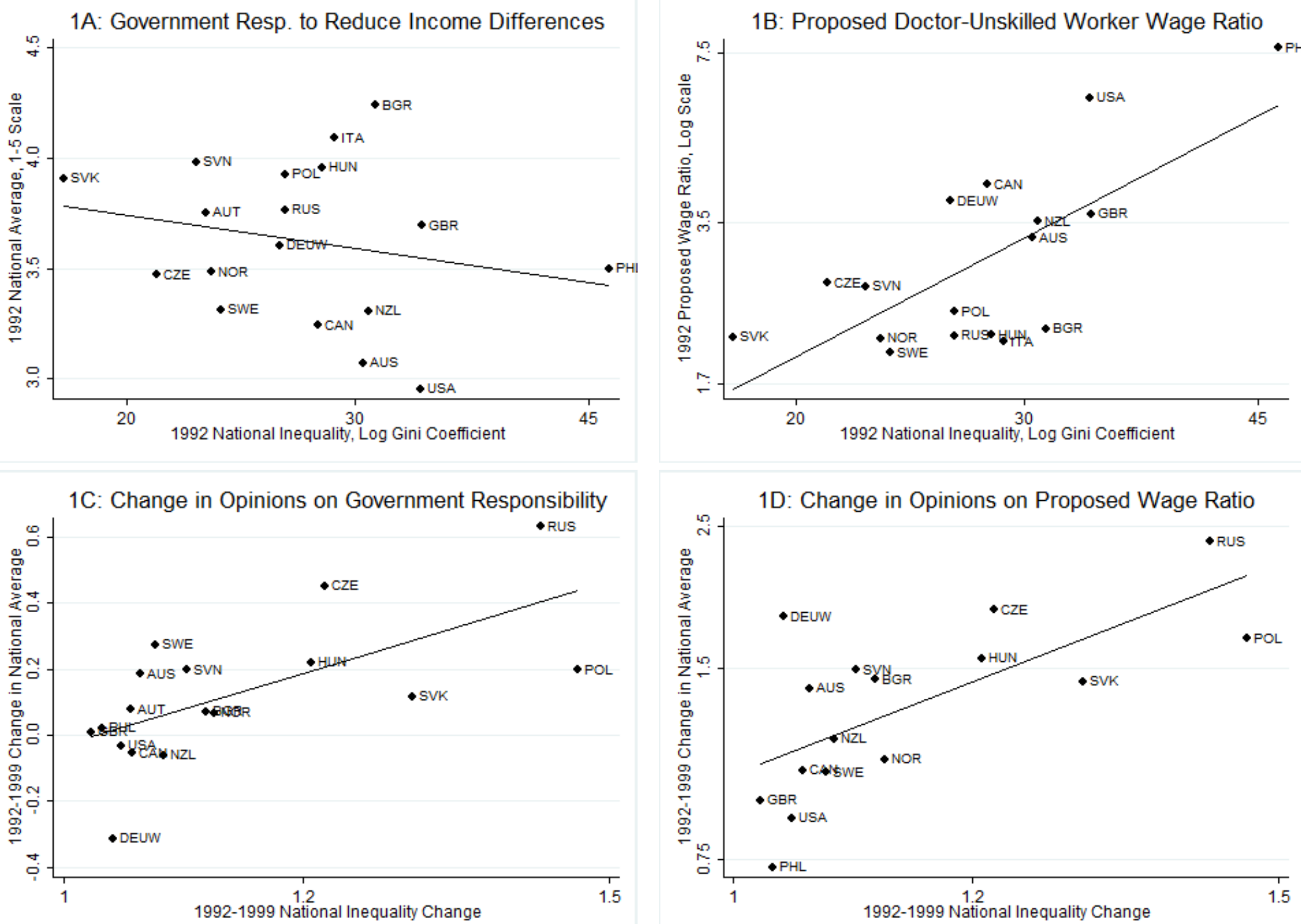

Notes: Panel 1A plots 1992 ISSP responses on the government's responsibility to reduce income differences, with higher values indicating greater responsibility. Panel $1 \mathrm{~B}$ plots the average proposed wage ratio for a doctor vs. unskilled worker. Countries with greater inequality express lower redistribution preferences and propose a wider wage distribution. Panels 1C and 1D consider 1992-1999 changes. Increased inequality is associated with greater redistribution support and wider proposed wage ratios. 


\section{Fig. 2: U.S. Welfare Spending Preferences and Regional Inequality}

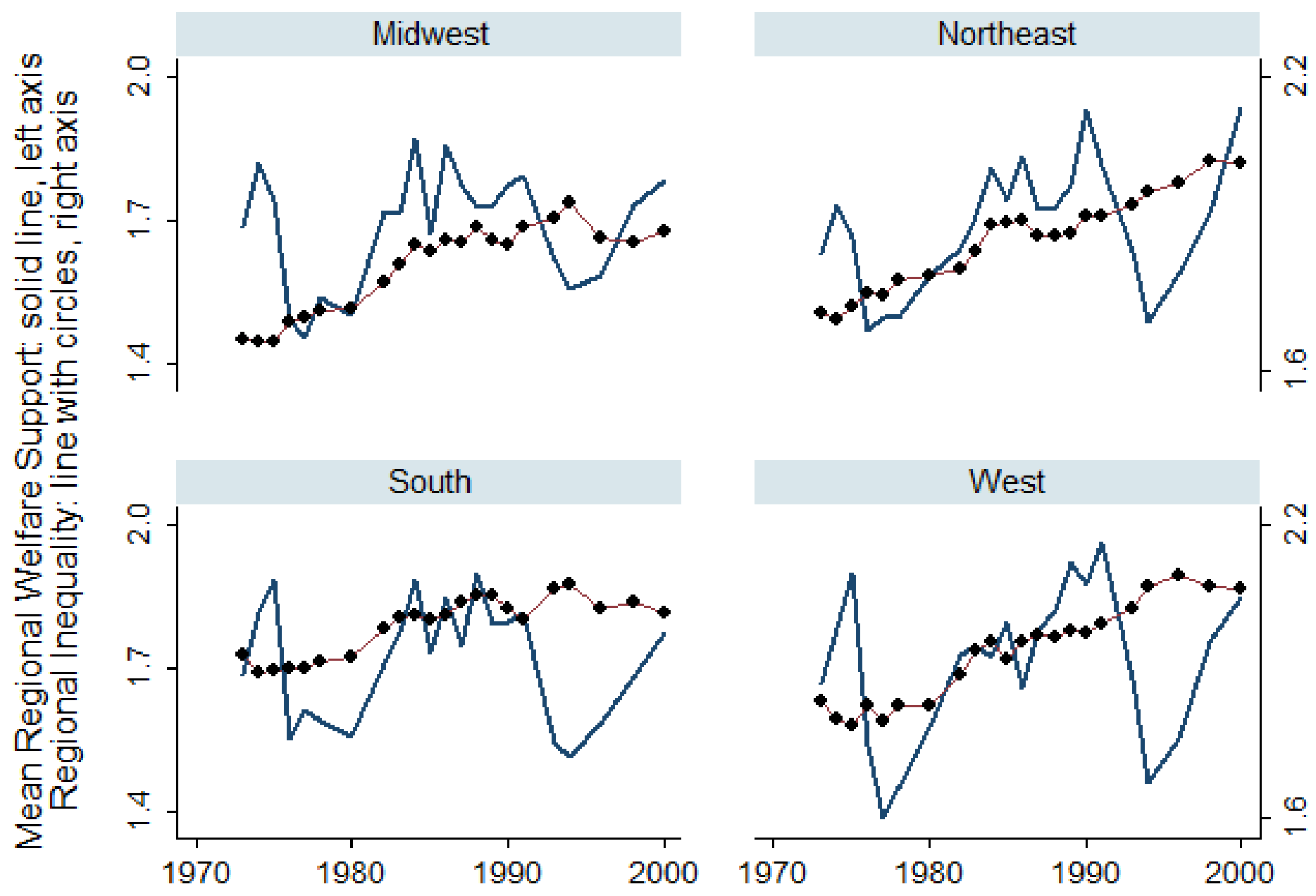

Notes: Figure plots the co-movement in U.S. regional inequality and average support for welfare spending among GSS respondents. The solid lines without circles are the average support on a three-point scale for greater welfare spending by respondents in the region, with higher values indicating greater support. The lines with circles are regional inequalities measured as the log 80-20 income differential from the March CPS. 


\section{Fig. 3: First Stage for U.S. Minimum-Wage Instrument}
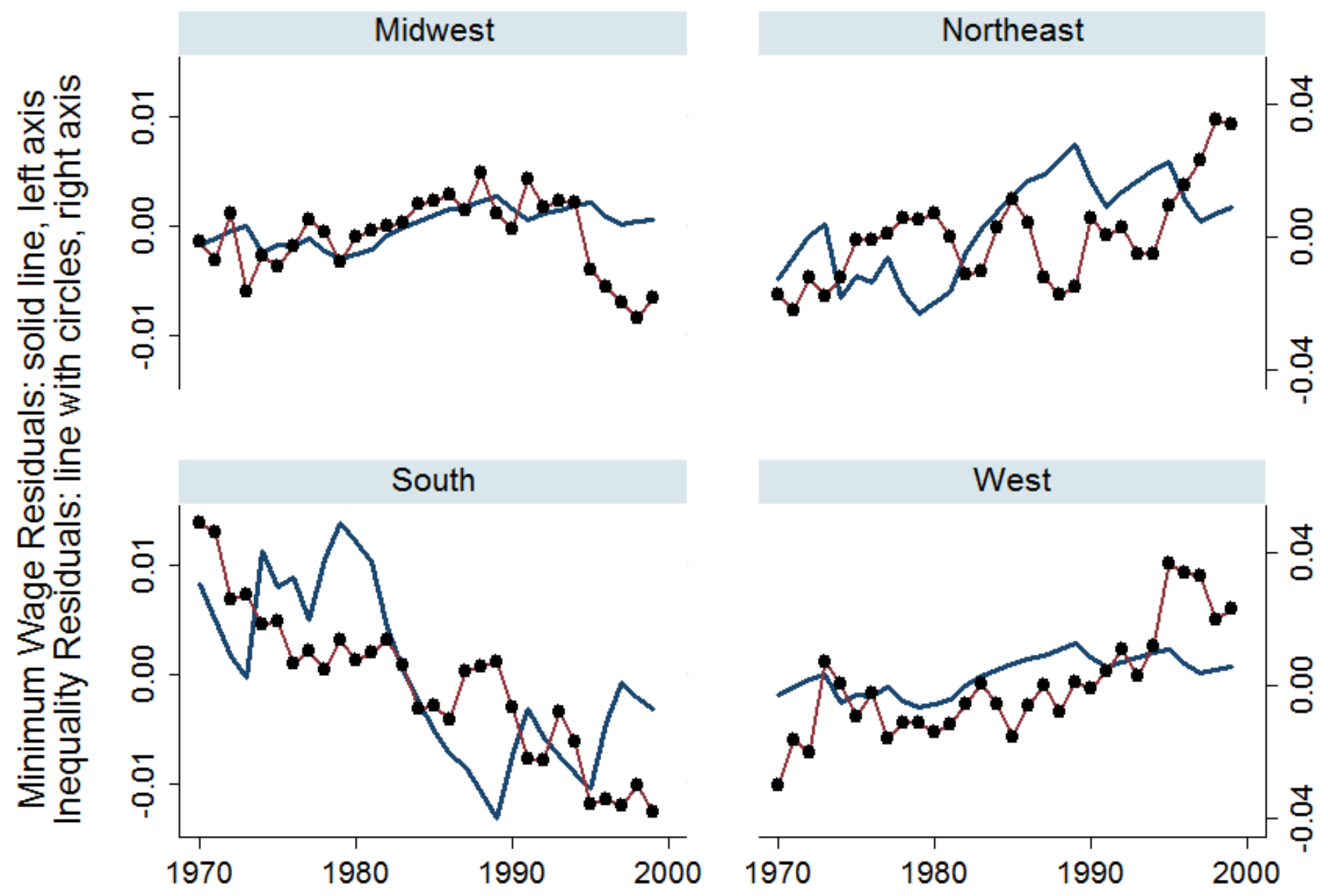

Notes: Figure plots the first-stage relationship between the U.S. minimum-wage instrument and regional inequality. The solid lines without circles are the residuals from regressing the minimum-wage instrument on region fixed effects, year fixed effects, and the region's log median income level. The lines with circles are the residuals for regional inequality similarly constructed. 


\begin{tabular}{|c|c|c|c|}
\hline & Total Sample & $\begin{array}{l}\text { Long-Term } \\
\text { OECD }\end{array}$ & $\begin{array}{l}\text { Non Long-Term } \\
\text { OECD }\end{array}$ \\
\hline & \multicolumn{3}{|c|}{ A. ISSP Social Inequality Panel } \\
\hline Countries & 19 & 11 & 8 \\
\hline Respondents & 54,091 & 31,083 & 23,008 \\
\hline $\begin{array}{l}\text { Government Responsibility } \\
\text { (1-5 Scale) }\end{array}$ & $\begin{array}{l}3.65 \\
(1.19)\end{array}$ & $\begin{array}{c}3.41 \\
(1.20)\end{array}$ & $\begin{array}{c}3.96 \\
(1.10)\end{array}$ \\
\hline $\begin{array}{l}\text { Progressive Taxation } \\
\text { (1-5 Scale) }\end{array}$ & $\begin{array}{c}4.02 \\
(0.77)\end{array}$ & $\begin{array}{l}3.97 \\
(0.73)\end{array}$ & $\begin{array}{l}4.10 \\
(0.82)\end{array}$ \\
\hline $\begin{array}{l}\text { Proposed Doctor-Unskilled } \\
\text { Wage Ratio }\end{array}$ & $\begin{array}{c}3.80 \\
(8.17)\end{array}$ & $\begin{array}{l}4.16 \\
(8.17)\end{array}$ & $\begin{array}{c}3.35 \\
(8.16)\end{array}$ \\
\hline $\begin{array}{l}\text { Inequality Acceptance } \\
\text { (1-5 Scale) }\end{array}$ & $\begin{array}{c}4.05 \\
(0.99)\end{array}$ & $\begin{array}{l}3.88 \\
(0.99)\end{array}$ & $\begin{array}{l}4.28 \\
(0.95)\end{array}$ \\
\hline $\begin{array}{l}\text { Poor-Rich Conflict } \\
\text { (1-4 Scale) }\end{array}$ & $\begin{array}{c}2.52 \\
(0.84)\end{array}$ & $\begin{array}{l}2.45 \\
(0.77)\end{array}$ & $\begin{array}{c}2.62 \\
(0.90)\end{array}$ \\
\hline $\begin{array}{l}\text { Young-Old Conflict } \\
\text { (1-4 Scale) }\end{array}$ & $\begin{array}{c}2.21 \\
(0.80)\end{array}$ & $\begin{array}{c}2.22 \\
(0.75)\end{array}$ & $\begin{array}{c}2.19 \\
(0.86)\end{array}$ \\
\hline \multirow[t]{2}{*}{ Log Gini Coefficient } & $\begin{array}{c}3.37 \\
(0.17)\end{array}$ & $\begin{array}{l}3.35 \\
(0.13)\end{array}$ & $\begin{array}{c}3.40 \\
(0.22)\end{array}$ \\
\hline & \multicolumn{3}{|c|}{ B. WVS Social Inequality Panel } \\
\hline Countries & 37 & 15 & 22 \\
\hline Respondents & 137,006 & 51,104 & 85,902 \\
\hline $\begin{array}{l}\text { WVS Income Equalization } \\
\text { (1-10 Scale) }\end{array}$ & $\begin{array}{l}5.25 \\
(3.01)\end{array}$ & $\begin{array}{c}5.31 \\
(2.73)\end{array}$ & $\begin{array}{c}5.22 \\
(3.17)\end{array}$ \\
\hline Log Gini Coefficient & $\begin{array}{c}3.51 \\
(0.30)\end{array}$ & $\begin{array}{c}3.35 \\
(0.16)\end{array}$ & $\begin{array}{c}3.60 \\
(0.32)\end{array}$ \\
\hline \multicolumn{4}{|c|}{$\begin{array}{l}\text { Notes: Table provides descriptive statistics on social preferences for income inequality and government } \\
\text { redistribution taken from the ISSP and WVS surveys. Survey responses are ordered such that higher } \\
\text { values indicate more concerned responses, excepting the proposed doctor-unskilled wage ratio. Variable } \\
\text { means are reported with standard deviations indicated in parentheses. Sample sizes in some regressions } \\
\text { are smaller than total respondents as some respondents skipped questions; surveys also varied on the } \\
\text { demographic and mobility information collected. ISSP Long-Term OECD Members include AUS, AUT, } \\
\text { CAN, DEU, GBR, ITA, JAP, NOR, NZL, SWE, and USA. ISSP Non-Long-Term OECD Members } \\
\text { include BGR, CZE, HUN, PHL, POL, RUS, SVK, and SVN. WVS Long-Term OECD Members } \\
\text { include AUT, BEL, CAN, DEU, ESP, FIN, FRA, GBR, IRL, ITA, JAP, NLD, NOR, SWE, and USA. } \\
\text { WVS Non-Long-Term OECD Members include ARG, BGR, BLR, BRA, CHL, CHN, CZE, EST, HUN, } \\
\text { IND, KOR, LTU, LVA, MEX, NGA, POL, ROM, RUS, SVK, SVN, TUR, and ZAF. }\end{array}$} \\
\hline
\end{tabular}


Table 2: ISSP and WVS Regressions with Aggregate Gini Inequality

\begin{tabular}{|c|c|c|c|c|c|}
\hline & \multirow[b]{2}{*}{$\begin{array}{c}\text { Base } \\
\text { Regression }\end{array}$} & \multicolumn{4}{|c|}{ Including Demographic and Mobility Controls } \\
\hline & & $\begin{array}{c}\text { Base } \\
\text { Regression }\end{array}$ & $\begin{array}{c}\text { Including } \\
\text { Worker } \\
\text { Controls }\end{array}$ & $\begin{array}{c}\text { Including } \\
\text { OECD-Yr. } \\
\text { Effects }\end{array}$ & $\begin{array}{c}\text { Including } \\
\text { Trans.-Yr. } \\
\text { Effects }\end{array}$ \\
\hline & $(1)$ & $(2)$ & $(3)$ & $(4)$ & $(5)$ \\
\hline & & \multicolumn{3}{|c|}{ A. Government Responsibility Responses } & \\
\hline $\begin{array}{l}\text { Log National } \\
\text { Gini Coefficient }\end{array}$ & $\begin{array}{c}0.161 \\
(0.048)\end{array}$ & $\begin{array}{c}0.153 \\
(0.049)\end{array}$ & $\begin{array}{c}0.158 \\
(0.051)\end{array}$ & $\begin{array}{c}0.129 \\
(0.056)\end{array}$ & $\begin{array}{c}0.093 \\
(0.058)\end{array}$ \\
\hline \multirow[t]{2}{*}{ Observations } & 54,054 & 45,918 & 45,918 & 45,918 & 45,918 \\
\hline & \multicolumn{5}{|c|}{ B. Progressive Taxation Responses } \\
\hline \multirow[t]{2}{*}{$\begin{array}{l}\text { Log National } \\
\text { Gini Coefficient }\end{array}$} & $\begin{array}{c}0.238 \\
(0.071)\end{array}$ & $\begin{array}{c}0.234 \\
(0.077)\end{array}$ & $\begin{array}{c}0.235 \\
(0.076)\end{array}$ & $\begin{array}{c}0.188 \\
(0.072)\end{array}$ & $\begin{array}{c}0.187 \\
(0.090)\end{array}$ \\
\hline & \multicolumn{5}{|c|}{ C. Inequality Acceptance Responses } \\
\hline \multirow[t]{2}{*}{$\begin{array}{l}\text { Log National } \\
\text { Gini Coefficient }\end{array}$} & $\begin{array}{c}0.160 \\
(0.046)\end{array}$ & $\begin{array}{c}0.142 \\
(0.045)\end{array}$ & $\begin{array}{c}0.148 \\
(0.046)\end{array}$ & $\begin{array}{c}0.084 \\
(0.049)\end{array}$ & $\begin{array}{c}0.072 \\
(0.067)\end{array}$ \\
\hline & \multicolumn{5}{|c|}{ D. Poor-Rich Conflict Responses } \\
\hline \multirow[t]{2}{*}{$\begin{array}{l}\text { Log National } \\
\text { Gini Coefficient }\end{array}$} & $\begin{array}{c}0.124 \\
(0.032)\end{array}$ & $\begin{array}{c}0.135 \\
(0.034)\end{array}$ & $\begin{array}{c}0.135 \\
(0.033)\end{array}$ & $\begin{array}{c}0.116 \\
(0.030)\end{array}$ & $\begin{array}{c}0.133 \\
(0.035)\end{array}$ \\
\hline & \multicolumn{5}{|c|}{ E. Young-Old Conflict Responses } \\
\hline \multirow[t]{2}{*}{$\begin{array}{l}\text { Log National } \\
\text { Gini Coefficient }\end{array}$} & $\begin{array}{l}-0.007 \\
(0.042)\end{array}$ & $\begin{array}{l}-0.007 \\
(0.039)\end{array}$ & $\begin{array}{l}-0.007 \\
(0.038)\end{array}$ & $\begin{array}{l}-0.071 \\
(0.060)\end{array}$ & $\begin{array}{l}-0.013 \\
(0.062)\end{array}$ \\
\hline & \multicolumn{5}{|c|}{ F. Log Proposed Doctor-Unskilled Wage Ratio Responses } \\
\hline \multirow[t]{3}{*}{$\begin{array}{l}\text { Log National } \\
\text { Gini Coefficient }\end{array}$} & $\begin{array}{c}0.256 \\
(0.089)\end{array}$ & $\begin{array}{c}0.238 \\
(0.081)\end{array}$ & $\begin{array}{c}0.239 \\
(0.080)\end{array}$ & $\begin{array}{c}0.302 \\
(0.080)\end{array}$ & $\begin{array}{c}0.241 \\
(0.089)\end{array}$ \\
\hline & \multicolumn{5}{|c|}{ WVS Panel } \\
\hline & \multicolumn{5}{|c|}{ G. WVS Income Equalization Responses } \\
\hline $\begin{array}{l}\text { Log National } \\
\text { Gini Coefficient }\end{array}$ & $\begin{array}{c}0.358 \\
(0.100)\end{array}$ & $\begin{array}{c}0.374 \\
(0.106)\end{array}$ & $\begin{array}{c}0.371 \\
(0.106)\end{array}$ & $\begin{array}{c}0.341 \\
(0.116)\end{array}$ & $\begin{array}{c}0.266 \\
(0.146)\end{array}$ \\
\hline Observations & 137,006 & 118,499 & 118,499 & 118,499 & 118,499 \\
\hline \multicolumn{6}{|c|}{$\begin{array}{l}\text { Notes: Regressions consider the relationship between national inequality and preferences for redistribution } \\
\text { and compensation differentials taken from ISSP and WVS. Survey responses are ordered such that higher } \\
\text { values indicate more concerned responses, excepting the proposed doctor-unskilled wage ratio. Regressions } \\
\text { include country and year fixed effects. Regressions include country-year controls for log GDP per capita, } \\
\text { share of workers in industry, and share of workers in services. Demographic Controls include sex, marital } \\
\text { status, age, education, and income dummies. Mobility Controls include respondents' views on the } \\
\text { determinants of success (e.g., knowledge, family connections) and comparisons of their jobs to their fathers' } \\
\text { jobs (ISSP). Work Controls include self-employed, unemployed, supervisor, and union-member dummies. } \\
\text { Inequality measures are lagged one period. Variables are transformed to have zero mean and unit standard } \\
\text { deviation. Regressions are weighted for nationally representative samples and equal cross-national weight. } \\
\text { Standard errors clustered by country are in parentheses. Observation counts for Government Responsibility } \\
\text { are representative for other ISSP variables. }\end{array}$} \\
\hline
\end{tabular}


Table 3A: GSS Regressions with Aggregate Gini Inequality

\begin{tabular}{|c|c|c|c|c|}
\hline & \multirow[b]{2}{*}{$\begin{array}{c}\text { Base } \\
\text { Regression }\end{array}$} & \multicolumn{3}{|c|}{ Including Demographic and Mobility Controls } \\
\hline & & $\begin{array}{c}\text { Base } \\
\text { Regression }\end{array}$ & $\begin{array}{l}\text { Including } \\
\text { Worker } \\
\text { Controls }\end{array}$ & $\begin{array}{c}\text { Including } \\
\text { Racial } \\
\text { Controls }\end{array}$ \\
\hline & $(1)$ & $(2)$ & $(3)$ & (4) \\
\hline & \multicolumn{4}{|c|}{ A. Welfare Spending Responses } \\
\hline $\begin{array}{l}\text { Log Regional } \\
\text { Gini Coefficient }\end{array}$ & $\begin{array}{c}0.130 \\
(0.035)\end{array}$ & $\begin{array}{c}0.135 \\
(0.035)\end{array}$ & $\begin{array}{c}0.114 \\
(0.039)\end{array}$ & $\begin{array}{c}0.132 \\
(0.031)\end{array}$ \\
\hline \multirow[t]{2}{*}{ Observations } & 24,247 & 21,965 & 14,704 & 21,965 \\
\hline & \multicolumn{4}{|c|}{ B. Income Equalization Responses } \\
\hline $\begin{array}{l}\text { Log Regional } \\
\text { Gini Coefficient }\end{array}$ & $\begin{array}{c}0.086 \\
(0.043)\end{array}$ & $\begin{array}{c}0.040 \\
(0.043)\end{array}$ & $\begin{array}{c}0.059 \\
(0.043)\end{array}$ & $\begin{array}{c}0.023 \\
(0.040)\end{array}$ \\
\hline \multirow[t]{2}{*}{ Observations } & 20,414 & 18,344 & 17,293 & 18,344 \\
\hline & \multicolumn{4}{|c|}{ C. Political Party Identification Responses } \\
\hline $\begin{array}{l}\text { Log Regional } \\
\text { Gini Coefficient }\end{array}$ & $\begin{array}{c}0.198 \\
(0.024)\end{array}$ & $\begin{array}{c}0.206 \\
(0.024)\end{array}$ & $\begin{array}{c}0.217 \\
(0.033)\end{array}$ & $\begin{array}{c}0.196 \\
(0.028)\end{array}$ \\
\hline \multirow[t]{2}{*}{ Observations } & 37,763 & 33,971 & 23,026 & 33,791 \\
\hline & \multicolumn{4}{|c|}{ D. Space Exploration Program Spending Responses } \\
\hline $\begin{array}{l}\text { Log Regional } \\
\text { Gini Coefficient }\end{array}$ & $\begin{array}{l}-0.044 \\
(0.031)\end{array}$ & $\begin{array}{l}-0.047 \\
(0.034)\end{array}$ & $\begin{array}{l}-0.067 \\
(0.032)\end{array}$ & $\begin{array}{l}-0.047 \\
(0.030)\end{array}$ \\
\hline Observations & 23,942 & 21,757 & 14,574 & 21,757 \\
\hline
\end{tabular}

Notes: Regressions consider the relationship between regional inequality and preferences for redistribution taken from GSS. Survey responses are ordered such that higher values indicate more concerned responses. Regressions include the log median income for each region, region fixed effects, and year fixed effects. Demographic Controls include sex, marital status, age, education, and income dummies. Mobility Controls include recent changes in family financial position. Work Controls include self-employed, unemployed, and union-member dummies. Racial Controls include non-white respondent dummy. Inequality measures are lagged one period. Variables are transformed to have zero mean and unit standard deviation. Bootstrapped standard errors are in parentheses. 
Table 3B: GSS Regressions with 80-20 Income Differential Inequality

\begin{tabular}{|c|c|c|c|c|}
\hline & \multirow[b]{2}{*}{$\begin{array}{c}\text { Base } \\
\text { Regression }\end{array}$} & \multicolumn{3}{|c|}{ Including Demographic and Mobility Controls } \\
\hline & & $\begin{array}{c}\text { Base } \\
\text { Regression }\end{array}$ & $\begin{array}{l}\text { Including } \\
\text { Worker } \\
\text { Controls }\end{array}$ & $\begin{array}{c}\text { Including } \\
\text { Racial } \\
\text { Controls }\end{array}$ \\
\hline & $(1)$ & $(2)$ & (3) & $(4)$ \\
\hline & \multicolumn{4}{|c|}{ A. Welfare Spending Responses } \\
\hline $\begin{array}{l}\text { Log Regional } \\
\text { 80/20 Differential }\end{array}$ & $\begin{array}{c}0.098 \\
(0.030)\end{array}$ & $\begin{array}{c}0.114 \\
(0.026)\end{array}$ & $\begin{array}{c}0.127 \\
(0.036)\end{array}$ & $\begin{array}{c}0.112 \\
(0.030)\end{array}$ \\
\hline \multirow[t]{2}{*}{ Observations } & 24,247 & 21,965 & 14,704 & 21,965 \\
\hline & \multicolumn{4}{|c|}{ B. Income Equalization Responses } \\
\hline $\begin{array}{l}\text { Log Regional } \\
\text { 80/20 Differential }\end{array}$ & $\begin{array}{c}0.099 \\
(0.024)\end{array}$ & $\begin{array}{c}0.040 \\
(0.039)\end{array}$ & $\begin{array}{c}0.051 \\
(0.035)\end{array}$ & $\begin{array}{c}0.026 \\
(0.028)\end{array}$ \\
\hline \multirow[t]{2}{*}{ Observations } & 20,414 & 18,344 & 17,293 & 18,344 \\
\hline & \multicolumn{4}{|c|}{ C. Political Party Identification Responses } \\
\hline $\begin{array}{l}\text { Log Regional } \\
\text { 80/20 Differential }\end{array}$ & $\begin{array}{c}0.135 \\
(0.022)\end{array}$ & $\begin{array}{c}0.164 \\
(0.022)\end{array}$ & $\begin{array}{c}0.173 \\
(0.029)\end{array}$ & $\begin{array}{c}0.158 \\
(0.028)\end{array}$ \\
\hline \multirow[t]{2}{*}{ Observations } & 37,763 & 33,971 & 23,026 & 33,791 \\
\hline & \multicolumn{4}{|c|}{ D. Space Exploration Program Spending Responses } \\
\hline $\begin{array}{l}\text { Log Regional } \\
\text { 80/20 Differential }\end{array}$ & $\begin{array}{c}0.002 \\
(0.026)\end{array}$ & $\begin{array}{l}-0.015 \\
(0.029)\end{array}$ & $\begin{array}{l}-0.021 \\
(0.038)\end{array}$ & $\begin{array}{l}-0.016 \\
(0.032)\end{array}$ \\
\hline Observations & 23,942 & 21,757 & 14,574 & 21,757 \\
\hline
\end{tabular}

Notes: See Table 3A. 
Table 4: GSS Regressions with Disaggregated Inequality

\begin{tabular}{|c|c|c|c|c|}
\hline & \multirow[b]{2}{*}{$\begin{array}{c}\text { Base } \\
\text { Regression }\end{array}$} & \multicolumn{3}{|c|}{ Including Demographic and Mobility Controls } \\
\hline & & $\begin{array}{c}\text { Base } \\
\text { Regression }\end{array}$ & $\begin{array}{c}\text { Including } \\
\text { Worker } \\
\text { Controls }\end{array}$ & $\begin{array}{c}\text { Including } \\
\text { Racial } \\
\text { Controls }\end{array}$ \\
\hline & $(1)$ & $(2)$ & $(3)$ & $(4)$ \\
\hline & \multicolumn{4}{|c|}{ A. Welfare Spending Responses } \\
\hline $\begin{array}{l}\text { Log Regional } \\
\text { 80/50 Differential }\end{array}$ & $\begin{array}{c}0.013 \\
(0.028)\end{array}$ & $\begin{array}{c}0.013 \\
(0.031)\end{array}$ & $\begin{array}{c}0.002 \\
(0.032)\end{array}$ & $\begin{array}{c}0.001 \\
(0.030)\end{array}$ \\
\hline $\begin{array}{l}\text { Log Regional } \\
\text { 50/20 Differential }\end{array}$ & $\begin{array}{c}0.072 \\
(0.020)\end{array}$ & $\begin{array}{c}0.084 \\
(0.023)\end{array}$ & $\begin{array}{c}0.098 \\
(0.030)\end{array}$ & $\begin{array}{c}0.086 \\
(0.027)\end{array}$ \\
\hline \multirow[t]{2}{*}{ Observations } & 24,247 & 21,965 & 14,704 & 21,965 \\
\hline & \multicolumn{4}{|c|}{ B. Income Equalization Responses } \\
\hline $\begin{array}{l}\text { Log Regional } \\
\text { 80/50 Differential }\end{array}$ & $\begin{array}{c}0.067 \\
(0.032)\end{array}$ & $\begin{array}{c}0.042 \\
(0.042)\end{array}$ & $\begin{array}{c}0.042 \\
(0.037)\end{array}$ & $\begin{array}{c}0.028 \\
(0.038)\end{array}$ \\
\hline $\begin{array}{l}\text { Log Regional } \\
\text { 50/20 Differential }\end{array}$ & $\begin{array}{c}0.046 \\
(0.026)\end{array}$ & $\begin{array}{c}0.011 \\
(0.030)\end{array}$ & $\begin{array}{c}0.020 \\
(0.032)\end{array}$ & $\begin{array}{c}0.007 \\
(0.029)\end{array}$ \\
\hline \multirow[t]{2}{*}{ Observations } & 20,414 & 18,344 & 17,293 & 18,344 \\
\hline & \multicolumn{4}{|c|}{ C. Political Party Identification Responses } \\
\hline $\begin{array}{l}\text { Log Regional } \\
\text { 80/50 Differential }\end{array}$ & $\begin{array}{c}0.036 \\
(0.027)\end{array}$ & $\begin{array}{c}0.035 \\
(0.026)\end{array}$ & $\begin{array}{c}0.002 \\
(0.032)\end{array}$ & $\begin{array}{c}0.015 \\
(0.024)\end{array}$ \\
\hline $\begin{array}{l}\text { Log Regional } \\
\text { 50/20 Differential }\end{array}$ & $\begin{array}{c}0.093 \\
(0.014)\end{array}$ & $\begin{array}{c}0.114 \\
(0.021)\end{array}$ & $\begin{array}{c}0.137 \\
(0.020)\end{array}$ & $\begin{array}{c}0.118 \\
(0.015)\end{array}$ \\
\hline \multirow[t]{2}{*}{ Observations } & 37,763 & 33,971 & 23,026 & 33,791 \\
\hline & \multicolumn{4}{|c|}{ D. Space Exploration Program Spending Responses } \\
\hline $\begin{array}{l}\text { Log Regional } \\
\text { 80/50 Differential }\end{array}$ & $\begin{array}{c}0.017 \\
(0.036)\end{array}$ & $\begin{array}{c}0.002 \\
(0.032)\end{array}$ & $\begin{array}{l}-0.008 \\
(0.033)\end{array}$ & $\begin{array}{c}0.010 \\
(0.036)\end{array}$ \\
\hline $\begin{array}{l}\text { Log Regional } \\
\text { 50/20 Differential }\end{array}$ & $\begin{array}{l}-0.006 \\
(0.019)\end{array}$ & $\begin{array}{l}-0.012 \\
(0.022)\end{array}$ & $\begin{array}{l}-0.013 \\
(0.026)\end{array}$ & $\begin{array}{l}-0.016 \\
(0.023)\end{array}$ \\
\hline Observations & 23,942 & 21,757 & 14,574 & 21,757 \\
\hline
\end{tabular}

Notes: See Tables 3A and 3B. 
Table 5A: GSS Gini Regressions with Minimum-Wage Instrument

\begin{tabular}{|c|c|c|c|c|}
\hline & \multirow[b]{2}{*}{$\begin{array}{c}\text { Base } \\
\text { Regression }\end{array}$} & \multicolumn{3}{|c|}{ Including Demographic and Mobility Controls } \\
\hline & & $\begin{array}{c}\text { Base } \\
\text { Regression }\end{array}$ & $\begin{array}{c}\text { Including } \\
\text { Worker } \\
\text { Controls }\end{array}$ & $\begin{array}{c}\text { Including } \\
\text { Racial } \\
\text { Controls }\end{array}$ \\
\hline & $(1)$ & $(2)$ & $(3)$ & (4) \\
\hline & \multicolumn{4}{|c|}{ A. Welfare Spending Responses } \\
\hline $\begin{array}{l}\text { Log Regional } \\
\text { Gini Coefficient }\end{array}$ & $\begin{array}{c}0.222 \\
(0.064)\end{array}$ & $\begin{array}{c}0.225 \\
(0.066)\end{array}$ & $\begin{array}{c}0.220 \\
(0.080)\end{array}$ & $\begin{array}{c}0.218 \\
(0.073)\end{array}$ \\
\hline \multirow[t]{2}{*}{ Observations } & 24,247 & 21,965 & 14,704 & 21,965 \\
\hline & \multicolumn{4}{|c|}{ B. Income Equalization Responses } \\
\hline $\begin{array}{l}\text { Log Regional } \\
\text { Gini Coefficient }\end{array}$ & $\begin{array}{c}0.122 \\
(0.112)\end{array}$ & $\begin{array}{c}0.079 \\
(0.089)\end{array}$ & $\begin{array}{c}0.095 \\
(0.093)\end{array}$ & $\begin{array}{c}0.063 \\
(0.124)\end{array}$ \\
\hline \multirow[t]{2}{*}{ Observations } & 20,414 & 18,344 & 17,293 & 18,344 \\
\hline & \multicolumn{4}{|c|}{ C. Political Party Identification Responses } \\
\hline $\begin{array}{l}\text { Log Regional } \\
\text { Gini Coefficient }\end{array}$ & $\begin{array}{c}0.220 \\
(0.049)\end{array}$ & $\begin{array}{c}0.247 \\
(0.061)\end{array}$ & $\begin{array}{c}0.204 \\
(0.058)\end{array}$ & $\begin{array}{c}0.239 \\
(0.054)\end{array}$ \\
\hline \multirow[t]{2}{*}{ Observations } & 37,763 & 33,971 & 23,026 & 33,971 \\
\hline & \multicolumn{4}{|c|}{ D. Space Exploration Program Spending Responses } \\
\hline $\begin{array}{l}\text { Log Regional } \\
\text { Gini Coefficient }\end{array}$ & $\begin{array}{l}-0.058 \\
(0.067)\end{array}$ & $\begin{array}{l}-0.038 \\
(0.062)\end{array}$ & $\begin{array}{l}-0.036 \\
(0.077)\end{array}$ & $\begin{array}{l}-0.041 \\
(0.070)\end{array}$ \\
\hline Observations & 23,942 & 21,757 & 14,574 & 21,757 \\
\hline
\end{tabular}

Notes: See Tables 3A and 3B. Estimated at the regional level and using bootstrapped standard errors, the first-stage coefficient for regional gini inequality is $1.50(0.40)$, with an F statistic of 11.7 and a partial $\mathrm{R}^{2}$ of 0.16 . 
Table 5B: GSS 80-20 Regressions with Minimum-Wage Instrument

\begin{tabular}{|c|c|c|c|c|}
\hline & \multirow[b]{2}{*}{$\begin{array}{c}\text { Base } \\
\text { Regression }\end{array}$} & \multicolumn{3}{|c|}{ Including Demographic and Mobility Controls } \\
\hline & & $\begin{array}{c}\text { Base } \\
\text { Regression }\end{array}$ & $\begin{array}{c}\text { Including } \\
\text { Worker } \\
\text { Controls }\end{array}$ & $\begin{array}{c}\text { Including } \\
\text { Racial } \\
\text { Controls }\end{array}$ \\
\hline & $(1)$ & $(2)$ & (3) & $(4)$ \\
\hline & \multicolumn{4}{|c|}{ A. Welfare Spending Responses } \\
\hline $\begin{array}{l}\text { Log Regional } \\
\text { 80/20 Differential }\end{array}$ & $\begin{array}{c}0.204 \\
(0.062)\end{array}$ & $\begin{array}{c}0.206 \\
(0.063)\end{array}$ & $\begin{array}{c}0.207 \\
(0.062)\end{array}$ & $\begin{array}{c}0.200 \\
(0.067)\end{array}$ \\
\hline \multirow[t]{2}{*}{ Observations } & 24,247 & 21,965 & 14,704 & 21,965 \\
\hline & \multicolumn{4}{|c|}{ B. Income Equalization Responses } \\
\hline $\begin{array}{l}\text { Log Regional } \\
\text { 80/20 Differential }\end{array}$ & $\begin{array}{c}0.128 \\
(0.090)\end{array}$ & $\begin{array}{c}0.070 \\
(0.091)\end{array}$ & $\begin{array}{c}0.083 \\
(0.109)\end{array}$ & $\begin{array}{c}0.055 \\
(0.080)\end{array}$ \\
\hline \multirow[t]{2}{*}{ Observations } & 20,414 & 18,344 & 17,293 & 18,344 \\
\hline & \multicolumn{4}{|c|}{ C. Political Party Identification Responses } \\
\hline $\begin{array}{l}\text { Log Regional } \\
\text { 80/20 Differential }\end{array}$ & $\begin{array}{c}0.209 \\
(0.050)\end{array}$ & $\begin{array}{c}0.232 \\
(0.053)\end{array}$ & $\begin{array}{c}0.196 \\
(0.060)\end{array}$ & $\begin{array}{c}0.224 \\
(0.062)\end{array}$ \\
\hline \multirow[t]{2}{*}{ Observations } & 37,763 & 33,971 & 23,026 & 33,971 \\
\hline & \multicolumn{4}{|c|}{ D. Space Exploration Program Spending Responses } \\
\hline $\begin{array}{l}\text { Log Regional } \\
\text { 80/20 Differential }\end{array}$ & $\begin{array}{l}-0.054 \\
(0.066)\end{array}$ & $\begin{array}{l}-0.035 \\
(0.065)\end{array}$ & $\begin{array}{l}-0.034 \\
(0.077)\end{array}$ & $\begin{array}{l}-0.038 \\
(0.068)\end{array}$ \\
\hline Observations & 23,942 & 21,757 & 14,574 & 21,757 \\
\hline
\end{tabular}

Notes: See Tables 3A and 3B. Estimated at the regional level and using bootstrapped standard errors, the first-stage coefficient for the regional $\log 80-20$ differential is 1.53 (0.53), with an F statistic of 7.3 and a partial $\mathrm{R}^{2}$ of 0.10 . 
Table 6: GSS Regressions with Extended Income Definitions and Regions

\begin{tabular}{|c|c|c|c|c|c|c|}
\hline \multirow{3}{*}{$\begin{array}{l}\text { Source of Log } \\
80 / 20 \text { Inequality } \\
\text { Metric }\end{array}$} & \multicolumn{3}{|c|}{ OLS } & \multicolumn{3}{|c|}{ IV } \\
\hline & Four & Nine & State & Four & Nine & State \\
\hline & Regions & Regions & Level & Regions & Regions & Level \\
\hline & $(1)$ & (2) & (3) & (4) & $(5)$ & $(6)$ \\
\hline & \multicolumn{6}{|c|}{ A. Welfare Spending Responses } \\
\hline Post-Tax Family & 0.114 & 0.061 & 0.081 & 0.206 & 0.194 & 0.151 \\
\hline Disposable Income & $(0.028)$ & $(0.028)$ & $(0.024)$ & $(0.061)$ & $(0.056)$ & $(0.065)$ \\
\hline Pre-Tax Family & 0.105 & 0.068 & 0.041 & 0.209 & 0.215 & 0.207 \\
\hline Labor Earnings & $(0.034)$ & $(0.023)$ & $(0.022)$ & $(0.057)$ & $(0.056)$ & $(0.089)$ \\
\hline Total Population & 0.030 & 0.056 & 0.067 & 0.593 & 0.227 & 0.157 \\
\hline \multirow[t]{2}{*}{ Hourly Wage } & $(0.020)$ & $(0.016)$ & $(0.018)$ & $(0.216)$ & $(0.069)$ & $(0.074)$ \\
\hline & \multicolumn{6}{|c|}{ B. Income Equalization Responses } \\
\hline Post-Tax Family & 0.040 & 0.027 & 0.068 & 0.070 & 0.042 & 0.125 \\
\hline Disposable Income & $(0.032)$ & $(0.030)$ & $(0.035)$ & $(0.074)$ & $(0.082)$ & $(0.211)$ \\
\hline Pre-Tax Family & 0.032 & 0.023 & 0.020 & 0.098 & 0.049 & 0.212 \\
\hline Labor Earnings & $(0.034)$ & $(0.023)$ & $(0.024)$ & $(0.149)$ & $(0.098)$ & $(0.333)$ \\
\hline Total Population & 0.054 & 0.018 & 0.053 & 0.305 & 0.047 & 0.268 \\
\hline \multirow[t]{2}{*}{ Hourly Wage } & $(0.021)$ & $(0.020)$ & $(0.027)$ & $(0.655)$ & $(0.163)$ & $(0.494)$ \\
\hline & \multicolumn{6}{|c|}{ C. Political Party Identification Responses } \\
\hline Post-Tax Family & 0.164 & 0.099 & 0.050 & 0.232 & 0.202 & 0.171 \\
\hline Disposable Income & $(0.027)$ & $(0.021)$ & $(0.020)$ & $(0.056)$ & $(0.040)$ & $(0.044)$ \\
\hline Pre-Tax Family & 0.143 & 0.100 & 0.018 & 0.250 & 0.226 & 0.218 \\
\hline Labor Earnings & $(0.024)$ & $(0.018)$ & $(0.017)$ & $(0.051)$ & $(0.047)$ & $(0.061)$ \\
\hline Total Population & 0.066 & 0.038 & 0.056 & 0.636 & 0.235 & 0.202 \\
\hline \multirow[t]{2}{*}{ Hourly Wage } & $(0.014)$ & $(0.014)$ & $(0.013)$ & $(0.180)$ & $(0.053)$ & $(0.060)$ \\
\hline & \multicolumn{6}{|c|}{ D. Space Exploration Program Spending Responses } \\
\hline Post-Tax Family & -0.015 & -0.006 & 0.012 & -0.035 & -0.022 & 0.005 \\
\hline Disposable Income & $(0.029)$ & $(0.023)$ & $(0.022)$ & $(0.061)$ & $(0.044)$ & $(0.067)$ \\
\hline Pre-Tax Family & -0.034 & -0.055 & -0.007 & -0.033 & -0.023 & 0.007 \\
\hline Labor Earnings & $(0.024)$ & $(0.029)$ & $(0.020)$ & $(0.071)$ & $(0.047)$ & $(0.073)$ \\
\hline Total Population & -0.022 & -0.006 & -0.012 & -0.109 & -0.032 & -0.005 \\
\hline Hourly Wage & $(0.021)$ & $(0.013)$ & $(0.017)$ & $(0.211)$ & $(0.072)$ & $(0.057)$ \\
\hline
\end{tabular}

Notes: See Tables 3A and 5A. Each coefficient is the result of a separate regression with the inequality measure indicated by the row title and the sample design indicated by the column header. Regressions include Demographic and Mobility Controls, the log median income for each geographic region, geographic region fixed effects, and year fixed effects. Median income covariates and geographic panel effects mirror the inequality measure employed. 


\section{Data Appendix}

This appendix describes the dataset construction for "Income Inequality and Social Preferences for Redistribution and Compensation Differentials".

\section{International Opinion Polls (ISSP and WVS)}

The international exercises employ the International Social Survey Programme (ISSP) and the World Value Survey (WVS). To maintain a consistent presentation across international and U.S. surveys, responses are ordered such that more-concerned views are associated with higher numbers.

The ISSP analysis focuses on the 1987, 1992, and 1999 Social Inequality module; the Government Responsibility and Progressive Taxation questions are also included in the 1985, 1990, and 1996 Role of the Government module. Responses to three complementary questions proxy social preferences for government-led income redistribution: the first focusing on the responsibility of the government in the transfer of income, the second considering progressive taxation, and the third considering the acceptability of current income differences:

Q. (Government Responsibility) "It is the responsibility of the government to reduce the differences in income between people with high incomes and those with low incomes."

1. Disagree strongly

2. Disagree

3. Neither agree nor disagree

4. Agree

5. Agree strongly

Q. (Progressive Taxation) "Do you think that people with high incomes should pay a larger share of their income in taxes than those with low incomes, the same share, or a smaller share?"

1. Much smaller share

2. Smaller

3. The same share

4. Larger

5. Much larger share

Q. (Inequality Acceptance) "Are differences in income in $<$ Respondent's country $>$ too large?"

1. Disagree strongly

2. Disagree 
3. Neither agree nor disagree

4. Agree

5. Agree strongly

Three important characteristics of these questions should be noted. They shy away from sensitive wording (e.g., words like "welfare" carry negative connotations) and they offer respondents a range of options that include a neutral stance. The Government Responsibility and Progressive Taxation questions also do not reference a country's current policy position (e.g.,

"do you think the government should be doing more to reduce the differences... "). Such relative questions are more difficult to evaluate in panel exercises.

Respondents are also asked their opinions on the appropriate salaries for a variety of occupations. Instructions request preferences be pre-tax and regardless of perceptions of current pay scales. From these responses, a Proposed Doctor-Unskilled Worker Wage Ratio is developed as the log ratio of the wages suggested for a "doctor in general practice" and an "unskilled worker in a factory". A higher ratio indicates a wider wage distribution (i.e., a ratio of one would indicate unskilled workers and doctors should earn the same amount). The reported results winsorize the raw ratio using the range $[0.5,100]$ prior to log transformation to limit the influence of outliers in descriptive exercises like Table 1. Regression analyses are very robust to adjustments of this procedure.

Other occupations present in all three Social Inequality surveys include a skilled factory worker, a government minister, and a chairman of a large national company. When discussing compensation differentials, the text also describes the evolution of the wage premiums between these positions. Unfortunately, some surveys substitute a representative value for a salary range or top code the maximum value. These adjustments have the most potential to influence the chairman salary, which is why this study focuses more on the doctor wage rate. Several techniques - dropping various survey years, using median estimations, imposing top codes, winsorizing - demonstrate very similar outcomes to the primary panel.

Finally, two questions regarding the presence of conflicts between social groups are employed. The first focuses on conflicts between the poor and the rich to validate respondents' awareness of the inequality in their countries, while a second question regarding conflict between young and old people is considered as a falsification exercise.

Q. (Poor-Rich Conflict) "In all countries there are differences or even conflicts between different social groups. In your opinion, in $<$ R's country $>$ how much conflict is there between poor people and rich people?"

1. No conflicts

2. Not very strong conflicts

3. Strong conflicts 


\section{Very strong conflicts}

Q. (Young-Old Conflict) "... between young people and older people?"

1. No conflicts

2. Not very strong conflicts

3. Strong conflicts

4. Very strong conflicts

As a complement to the ISSP, this study also considers responses to a question included in the 1990, 1995, and 2000 rounds of the WVS. This question (WVS Income Equalization) asks respondents to rate their views regarding income equalization on a ten-point scale. Ten is labeled, "Incomes should be made more equal." One is labeled, "We need larger income differences as incentives for individual effort." While the WVS panel enjoys a more-diverse group of developing economies, interpretation of this question is limited by its reference to the country's current position (i.e., more equal, larger differences) and asymmetric labeling of the two extreme values. Nevertheless, finding quantitatively and qualitatively similar results in a different sample is an important robustness check.

\section{International Inequality Series}

This subsection details the construction of the international gini estimates employed in the main text. Nations participating in multiple International Social Survey Programme (ISSP) or World Values Survey (WVS) rounds are included, although the former is this study's primary interest. Table A1 documents the constructed series and outlines the data sources. Data collection relied heavily on the United Nations Development Programme's World Income Inequality Database (versions 1.0 and 2.0c), the Luxembourg Income Study (LIS), Gottschalk and Smeeding (1997, 2000), and the individual publications of national statistics agencies. The WIID1 includes the earlier work of Deininger and Squire (1996) and was the original basis for this study. WIID2 is a 2008 revision that has been used to confirm the earlier series and extend where feasible to include additional survey responses. ${ }^{1}$

The target gini concept is disposable household income based upon a nationally representative sample. Although many sources, including LIS, divide by the square root of the household size, equivalency scales are not consistent across countries. Data limitations prevent consideration of gross (pre-transfers) household-income inequality. Gross metrics have the theoretical advantage of being less influenced by current and past preferences for redistribution, although one can argue disposable-income differences are what respondents are recalling when questioned. In

\footnotetext{
${ }^{1}$ The task here is to develop gini series covering the years included in the two survey programs. In doing so, a longer horizon is often considered than what the surveys require for a particular country to establish more confidence in the trends developed. These series, however, do not exhaust the inequality data available; gaps in the sequences do not necessarily mean appropriate gini estimates are not available.
} 
the U.S. portion of this study, the form of inequality (e.g., gross versus disposable household income, household labor earnings, hourly wage) is not critical for the results. A one-year lag in inequality is targeted for each survey round, but contemporaneous and two-year or three-year lagged measures are also accepted when necessary.

Selected series include multiple observations derived with a consistent technique and dataset. Other sources not listed in Table A1 are also used to substantiate both levels and trends of the chosen series, as well as to provide comparisons for how other income concepts are behaving during the same period. In a number of cases, two or three series are pieced together to span the time frame of this study (or as much of it as possible). In such cases, observations must share a common or adjoining year as a levels check; moreover, overlapping intervals are examined when available to ensure the series are following similar trends. Auxiliary series are also employed in these exercises for verification purposes. Finally, the gini estimates are rescaled to match the levels of LIS estimates around 1990 if the LIS is not employed directly in the construction of the series (participating countries only).

Atkinson and Brandolini (2001) outline a number of pitfalls that can occur when piecing together series from secondary datasets. The dataset developed for this study attempts to address these concerns while still assembling a meaningful panel of countries. However, it certainly falls short of achieving "double harmonization" across countries and time, and Kerr (2005) identifies questionable series due to poor quality data, alternative income concepts, splicing concerns, and so on. The consistency of the results across the ISSP and WVS samples, dropping low-quality series, and looking at harmonized U.S. inequalities should nevertheless instill confidence that the findings of this study are not the product of irregularities in the constructed series. ${ }^{2}$

\section{U.S. Opinion Poll (GSS)}

Social preferences for the United States are estimated from the General Social Survey (GSS), which has been conducted on an annual or biennial basis since 1972 with sample sizes ranging from 1400 to 3000 adults. This study focuses on a question that has been included for the full term of the survey. The question gauges respondent attitudes towards spending more or less money on welfare, while a similar question regarding spending for the space exploration program is used for contrast:

Q. (Welfare Spending) "Are we spending too much money, too little money, or about the right amount on welfare?"

1. Too much

2. About right

3. Too little

\footnotetext{
${ }^{2}$ Macroeconomic covariates are taken from the United Nations. The sector distribution covariates employ the "Value added, national currency, constant prices, by industry groups (WB estimates) [code 29915]" series.
} 
A third question, included in most surveys since 1978, asks respondents to rate on a sevenpoint scale how much the federal government should concern itself with the income differences between the rich and poor (GSS Income Equalization). Seven is labeled, "The government ought to reduce income differences between the rich and poor." One is labeled, "The government should not concern itself with reducing income differences."

For both the Welfare Spending and GSS Income Equalization questions, alternative versions are included in some years (e.g., substituting "assistance to the poor" for "welfare"). As the mean responses shift significantly with these alternative word choices, these questions are not incorporated; a visual check indicates trends for these alternative questions mirror those of the main questions. It should also be noted that the Welfare Spending question references current policies. Luttmer (2001) considers several corrections for this relative inquiry, finding his results using the base question alone are robust. This study does not attempt any such corrections.

Finally, respondents since 1972 are asked their political-party preference and the strength of this association on a seven-point scale.

Q. (Party Identification) "Generally speaking, do you usually think of yourself as a Republican, Democrat, Independent, or what?"

1. Strong Republican

2. Not very strong Republican

3. Independent, close to Republican

4. Independent (Neither, No Response)

5. Independent, close to Democrat

6. Not very strong Democrat

7. Strong Democrat

\section{$5 \quad$ U.S. Inequality Series}

Table A2 provides the federal minimum wage ratios and expected regional coverage ratios used to construct the minimum-wage instrument employed in the U.S. analysis. The last four columns also document the $\log 80-20$ income ratios employed in the primary estimations. The robustness of the instrument design has been verified on several dimensions. First, the results are mostly robust to simply fixing the coverage rate at its 1970 level for each region; the only trouble spot is in regressions that contain only year and region fixed effects, as the simpler interaction captures some of the median-income level trend when it is excluded. Second, the total industrial composition of the region can be substituted for the industrial composition of the poor workers. Finally, as noted above, the instrument incorporates two aggregate trends - changes in the federal rate and changes in industry coverage rates. Close observation shows the instrument can work against itself. Focusing on movements in the minimum-wage level, the instrument correctly predicts regions with higher coverage levels will be more affected by federal changes. Yet, over 
a short horizon and holding the minimum wage fixed, the instrument incorrectly predicts an increase in the coverage rate will raise inequality if the real federal rate is below its 1970 level; its predicted direction is correct if the real federal rate is above its 1970 level. An alternative specification removes the competing effects by using two instruments, one interacting the dynamics of the federal rate with fixed 1970 coverage rates and the second interacting industry coverage rate trends with the 1970 industrial composition. The results are again very close to those presented in the main text.

\section{References}

[1] Atkinson, Anthony, "The Changing Distribution of Income: Evidence and Explanations", German Economic Review, 1:1 (2000), 3-18.

[2] Atkinson, Anthony, and Andrea Brandolini, "Promise and Pitfalls in the Use of Secondary Data-Sets: Income Inequality in OECD Countries as a Case Study", Journal of Economic Literature, 34:3 (2001), 771-799.

[3] Brandolini, Andrea, "The Distribution of Personal Income in Post-War Italy: Source Description, Data Quality, and the Time Pattern of Income Inequality", Banca D'Italia Working Paper 350 (1999).

[4] Danziger, Sheldon, and Peter Gottschalk, America Unequal (Cambridge, M.A.: Harvard University Press, 1995).

[5] Deininger, Klaus, and Lyn Squire, "A New Data Set Measuring Income Inequality", The World Bank Economic Review, 10:3 (1996), 565-592.

[6] Fanjul, Gonzalo, and Victor Renes, "Spain Report" (2002).

[7] Frick, Jaochim, and Markus Grabka, "The Personal Distribution of Income and Imputed Rent - A Cross-National Comparison for the UK, West Germany, and the USA", DIW Berlin Working Paper 271 (2002).

[8] Goodman, Alissa, "Inequality and Living Standards in Great Britain: Some Facts", Institute for Fiscal Studies Briefing Note 19 (2001).

[9] Gottschalk, Peter, and Timothy Smeeding, "Empirical Evidence on Income Inequality in Industrialized Countries", LIS Working Paper 154 (1999).

[10] Gottschalk, Peter, and Timothy Smeeding, "Empirical Evidence on Income Inequality in Industrialized Countries", in Atkinson, Anthony, and Francois Bourguignon, ed., Handbook of Income Distribution, Volume 1 (Elsevier North-Holland Pergamon, 2000), 261-307.

[11] Kerr, William, "Income Inequality and Social Norms for Compensation Differentials and Government-Led Redistribution", Chapter 4, MIT Economics Ph.D. Dissertation (2005).

[12] Luxembourg Income Study (LIS) Key Figures, http://www.lisproject.org/keyfigures.htm.

[13] Ovtcharova, Lilia, "What Kind of Poverty Alleviation Policy Does Russia Need?", RussianEuropean Centre for Economic Policy Research Paper (2001). 
[14] Rupnik, Carlo, Margaret Thompson-James, and Ray Bollman, "Measuring Economic WellBeing of Rural Canadians Using Income Indicators", Statistics Canada Agriculture and Rural Working Paper Series 45 (2001).

[15] Statistics Australia: Australia Bureau of Statistics, "Australian Social Trends 2002" (2002).

[16] Statistics Japan: Statistics Bureau and Statistics Center, "1999 National Survey of Family Income and Expenditure" (2002).

[17] Statistics Korea: Korea National Statistics Office, "Household Income and Expenditure Survey" (2002). Data collected from multiple surveys.

[18] Statistics New Zealand: Statistics New Zealand, "New Zealand Now: Incomes" (1999).

[19] Statistics Norway: Statistics Norway, "Recent Trends in Income Inequality in Norway" (2002).

[20] Statistics Philippines: National Statistics Office, "Family Income and Expenditure Survey" (2002). Data collected from multiple surveys.

[21] Statistics United States: United States Census Bureau, "The Changing Shape of the Nation's Income Distribution: Consumer Income" (2000).

[22] UNU/WIDER-UNDP World Income Inequality Database, Version 1.0, September 2000.

[23] UNU/WIDER-UNDP World Income Inequality Database, Version 2.0c, May 2008. 
Table A1: Gini Coefficients

\begin{tabular}{|c|c|c|c|c|c|c|c|c|c|c|c|c|c|c|c|c|c|c|c|c|c|}
\hline Country & 1980 & 1981 & 1982 & 1983 & 1984 & 1985 & 1986 & 1987 & 1988 & 1989 & 1990 & 1991 & 1992 & 1993 & 1994 & 1995 & 1996 & 1997 & 1998 & 1999 & 2000 \\
\hline ARG & 37.0 & & & & & & & & & & 43.1 & 44.1 & 43.6 & 43.8 & 46.3 & 45.8 & 44.8 & 46.7 & & & \\
\hline AUS & & 28.1 & & & & 29.2 & & & & 30.4 & & & & & 31.1 & 32.0 & 31.5 & 30.9 & 32.2 & & \\
\hline AUT & 21.8 & 21.8 & 21.8 & 22.3 & 22.3 & 22.3 & 22.3 & 22.7 & 22.7 & 22.7 & 22.7 & 23.1 & & & 28.0 & 27.7 & 26.6 & & 24.3 & & \\
\hline BEL & & & & & & 22.7 & & & 23.2 & & & & 22.4 & & & & & 25.0 & & & \\
\hline BGR & & & & & & & & & & 24.3 & & & 31.1 & 31.9 & 35.6 & 37.2 & 34.8 & 34.6 & & & \\
\hline BLR & & & & & & & & & 23.0 & & & & & & 28.0 & & & & & 26.0 & \\
\hline BRA & & 55.3 & & 56.2 & 55.5 & 56.7 & 55.9 & 57.0 & 58.6 & 59.5 & 58.3 & & & & & & 58.1 & & & & \\
\hline CAN & 28.2 & 27.6 & 27.8 & 28.6 & 28.3 & 28.2 & 28.3 & 28.1 & 27.9 & 27.7 & 27.7 & 28.1 & 27.8 & 28.1 & 27.7 & 28.0 & 29.0 & 29.5 & 29.6 & & \\
\hline CHE & & & 30.9 & & & & & & & & & & 30.7 & & & & & & & & \\
\hline CHL & & & & & & & & 56.1 & & & 55.1 & & 54.7 & & 54.9 & & 54.8 & & 55.5 & & 55.2 \\
\hline $\mathrm{CHN}$ & & & & & & & & & 38.2 & 38.0 & 39.3 & 38.9 & 39.7 & 40.6 & 41.8 & 43.1 & & & & & \\
\hline CZE & & & & & & & & & & 20.4 & & 21.2 & 21.4 & 25.8 & 26.0 & 28.2 & 25.4 & 25.9 & 25.8 & 25.7 & 27.0 \\
\hline DEU & 25.4 & & & 25.0 & & 26.0 & & 25.2 & & & 26.0 & 26.3 & 26.4 & 27.4 & & 27.5 & & & 27.3 & & \\
\hline DNK & & & & & & & & 25.4 & & & & & 23.6 & & & 26.3 & & 25.7 & & & \\
\hline ESP & 34.5 & & & & & & & & & & 32.4 & & & & & 37.1 & & & & & 34.6 \\
\hline EST & & & & & & & & & & & & & 41.2 & 38.8 & 39.6 & 39.0 & 37.4 & 34.1 & & & \\
\hline FIN & & & & & & & 21.3 & 20.7 & 21.2 & 21.3 & 21.2 & 21.0 & 20.7 & 21.8 & 21.6 & 21.8 & 22.6 & 23.6 & & & \\
\hline FRA & & & & & 29.0 & & & & & & 28.0 & & & & & & & 27.0 & & 27.0 & \\
\hline GBR & 25.3 & 25.9 & 25.8 & 26.4 & 26.6 & 27.9 & 28.8 & 30.2 & 32.0 & 32.4 & 33.7 & 33.7 & 34.0 & 33.7 & 33.0 & 33.0 & 33.3 & 33.8 & 34.4 & 34.2 & \\
\hline HUN & & 26.7 & 26.7 & & & & & 30.7 & & 29.7 & & 28.3 & & 31.4 & 32.1 & 33.7 & 33.9 & 34.1 & & & \\
\hline IND & & & & 33.4 & & & & 35.6 & 35.6 & & 35.6 & 34.0 & 35.5 & & 34.5 & 33.4 & 35.4 & 36.1 & & 36.1 & \\
\hline IRL & 36.0 & & & & & & & 35.2 & & & & & & & 35.3 & & & & 36.4 & & \\
\hline ISR & & & 30.0 & & & & 30.8 & & & & & & 30.5 & & & & & 33.6 & & & \\
\hline
\end{tabular}


Table A1: Gini Coefficients (continued)

\begin{tabular}{|c|c|c|c|c|c|c|c|c|c|c|c|c|c|c|c|c|c|c|c|c|c|}
\hline Country & 1980 & 1981 & 1982 & 1983 & 1984 & 1985 & 1986 & 1987 & 1988 & 1989 & 1990 & 1991 & 1992 & 1993 & 1994 & 1995 & 1996 & 1997 & 1998 & 1999 & 2000 \\
\hline ITA & 30.9 & 30.3 & 28.4 & 28.9 & 29.8 & 29.9 & 29.9 & 31.6 & & 29.3 & & 28.9 & & 32.2 & & 32.0 & & & 32.9 & & 31.6 \\
\hline JAP & & & & & 28.0 & & & & & 29.3 & & & & & 29.7 & & & & & 30.1 & \\
\hline KOR & 34.9 & & & & & 31.2 & & & & 30.4 & 29.5 & 28.7 & 28.4 & 28.1 & 28.5 & 28.4 & 29.1 & 28.3 & 31.6 & 32.0 & 31.7 \\
\hline LTU & & & & & & & & & & 26.0 & & & 37.2 & & 34.9 & 34.1 & 35.0 & & & & \\
\hline LVA & & & & & & & & & & & 22.5 & 22.5 & 29.6 & 24.5 & 30.7 & 31.7 & 32.2 & & & & \\
\hline MEX & & & & & 44.8 & & & & & 46.7 & & & 48.5 & & 49.6 & & 47.7 & & 49.4 & & \\
\hline NGA & & & & & & & & & & & & 45.0 & & 45.0 & & & & 50.6 & & & \\
\hline NLD & & 23.9 & & 23.5 & & 24.7 & & & 25.6 & 25.5 & 25.8 & 26.6 & 27.8 & 27.7 & 27.8 & 28.3 & & & & 28.0 & \\
\hline NOR & 22.5 & & & & & & 22.2 & 22.3 & 21.9 & 23.4 & 22.8 & 23.3 & 23.7 & 24.3 & 25.4 & 24.8 & 25.7 & 26.1 & & & \\
\hline NZL & & & 25.9 & & 26.0 & & 25.3 & & 25.8 & 28.0 & 29.9 & 30.7 & 29.9 & 31.8 & 31.0 & 31.8 & 32.2 & 33.1 & & & \\
\hline PHL & & & & & & 44.6 & & & 44.5 & & & 46.8 & & & 45.1 & & & 48.7 & & 48.2 & \\
\hline POL & & & & & & & 27.7 & 28.1 & 27.6 & 28.6 & & 26.5 & 27.4 & 36.2 & 37.3 & 36.9 & 37.8 & 39.0 & & & \\
\hline ROM & & & & & & & & & & & & & & 22.6 & & & & 35.2 & 35.8 & & \\
\hline RUS & & & & & & & & & & 26.5 & 28.5 & 26.5 & 28.9 & 39.8 & 40.9 & 38.1 & 37.5 & 37.5 & 37.9 & 39.4 & \\
\hline SVK & & & & & & & & & & 18.1 & 17.8 & 18.0 & 18.6 & 19.7 & 20.8 & 20.0 & 24.8 & 23.4 & & & \\
\hline SVN & & & & & & & & & & 19.0 & 20.1 & 22.7 & 22.6 & 25.0 & 22.0 & 23.4 & 24.0 & 25.0 & & 24.9 & \\
\hline SWE & & 19.7 & & & & & & 21.8 & & 22.1 & 22.3 & 23.7 & 22.9 & 23.4 & 26.2 & 23.3 & 24.3 & 26.2 & 25.4 & 26.7 & \\
\hline TUR & & & & & & & & & & 43.6 & & & & & & 41.5 & & & & & 40.0 \\
\hline USA & 31.2 & 31.5 & 32.3 & 32.5 & 32.5 & 33.0 & 33.2 & 33.3 & 33.4 & 33.9 & 33.6 & 33.6 & 34.1 & 35.6 & 35.8 & 35.3 & 34.5 & 35.0 & 35.1 & & \\
\hline $\mathrm{ZAF}$ & & & & & & & & & & & 63.0 & & & & & 59.0 & & & & & 57.8 \\
\hline
\end{tabular}

Notes: Table documents country-year gini observations used with ISSP and WVS estimations. The target gini estimates are one-year lags from the survey date, although contemporaneous or two-year or three-year lags are accepted when necessary. Survey responses are dropped if they do not meet these conditions. Kerr (2005) provides greater details on these calculations. 


\begin{tabular}{|c|c|}
\hline Country & Sources \\
\hline ARG (Argentina) & WIID1 (5 NOOK) \\
\hline AUS (Australia) & Gottschalk and Smeeding (2000), LIS, Statistics Australia (2002) \\
\hline AUT (Austria) & LIS, WIID1 (4), WIID2 (1) \\
\hline BEL (Belgium) & LIS \\
\hline BGR (Bulgaria) & WIID1 (1), World Bank \\
\hline BLR (Belarus) & WIID1 (5), WIID2 (2) \\
\hline BRA (Brazil) & WIID1 (1) \\
\hline CAN (Canada) & Gottschalk and Smeeding (2000), LIS, Rupnik et al. (2001) \\
\hline CHE (Switzerland) & LIS \\
\hline CHL (Chile) & WIID1 (1), WIID2 (2) \\
\hline CHN (China) & WIID1 (1) \\
\hline CZE (Czech Rep.) & LIS, WIID1 (1), WIID2 $(1,2)$ \\
\hline DEU (W. Germany) & Frick and Grabka (2002), Gottschalk and Smeeding (2000), LIS, WIID1 (1) \\
\hline DNK (Denmark) & Gottschalk and Smeeding (2000), LIS \\
\hline ESP (Spain) & Fanjul and Renes (2002), LIS, WIID2 (1) \\
\hline EST (Estonia) & WIID1 (1) \\
\hline FIN (Finland) & Gottschalk and Smeeding (2000), WIID1 (1) \\
\hline FRA (France) & Gottschalk and Smeeding (2000), LIS, WIID2 (2) \\
\hline GBR (Great Britain) & Goodman (2001), Gottschalk and Smeeding (2000) \\
\hline HUN (Hungary) & LIS, WIID1 (1) \\
\hline IND (India) & WIID1 (3), WIID2 (2) \\
\hline IRL (Ireland) & Gottschalk and Smeeding (2000), LIS, WIID1 (1), WIID2 (1) \\
\hline ISR (Israel) & Gottschalk and Smeeding (2000), LIS \\
\hline ITA (Italy) & Brandolini (1999), Gottschalk and Smeeding (2000), WIID2 (1) \\
\hline JAP (Japan) & Gottschalk and Smeeding (2000), Statistics Japan (2002) \\
\hline KOR (South Korea) & WIID1 (1), Statistics Korea (2002) \\
\hline LTU (Lithuania) & WIID1 (4), WIID2 (2) \\
\hline LVA (Latvia) & WIID1 (4) \\
\hline MEX (Mexico) & LIS \\
\hline NGA (Nigeria) & WIID1 (1) \\
\hline NLD (Netherlands) & Gottschalk and Smeeding (2000), LIS, WIID2 (1) \\
\hline NOR (Norway) & Brandolini (1999), Gottschalk and Smeeding (2000), Statistics Norway (2002), WIID1 (1) \\
\hline NZL (New Zealand) & Statistics New Zealand (1999) \\
\hline PHL (Philippines) & Statistics Philippines (2002) \\
\hline POL (Poland) & LIS, WIID1 (1) \\
\hline ROM (Romania) & WIID2 (2) \\
\hline RUS (Russia) & LIS, Ovtcharova (2001) \\
\hline SVK (Slovakia) & WIID1 (1) \\
\hline SVN (Slovenia) & LIS, WIID1 $(1,4)$ \\
\hline SWE (Sweden) & Gottschalk and Smeeding (2000), LIS, WIID1 (1) \\
\hline TUR (Turkey) & WIID2 (3) \\
\hline USA (United States) & Gottschalk and Smeeding (2000), United States Census Bureau (2000) \\
\hline ZAF (South Africa) & WIID1 (1), WIID2 (3) \\
\hline
\end{tabular}


Table A2: Minimum-Wage Instrument Descriptive Statistics

\begin{tabular}{|c|c|c|c|c|c|c|c|c|c|c|c|}
\hline \multirow[b]{2}{*}{ Year } & \multirow{2}{*}{$\begin{array}{l}\text { Nominal } \\
\text { M. Wage }\end{array}$} & \multirow{2}{*}{$\begin{array}{c}\text { Real } \\
\text { M. Wage }\end{array}$} & \multirow{2}{*}{$\begin{array}{c}\text { Log Ratio } \\
\text { to } 1970\end{array}$} & \multicolumn{4}{|c|}{ Expected Coverage Ratios } & \multicolumn{4}{|c|}{ Log 80-20 Family Disposable Income } \\
\hline & & & & Northeast & Midwest & South & West & Northeast & Midwest & South & West \\
\hline 1970 & 1.60 & 5.03 & 0.00 & 89.9 & 87.1 & 78.4 & 87.2 & 0.500 & 0.487 & 0.638 & 0.527 \\
\hline 1971 & 1.60 & 4.81 & 0.04 & 89.9 & 87.1 & 78.3 & 87.2 & 0.509 & 0.495 & 0.649 & 0.555 \\
\hline 1972 & 1.60 & 4.59 & 0.09 & 89.9 & 87.1 & 78.3 & 87.2 & 0.525 & 0.515 & 0.635 & 0.557 \\
\hline 1973 & 1.60 & 4.46 & 0.12 & 90.2 & 87.5 & 78.9 & 87.6 & 0.532 & 0.504 & 0.649 & 0.597 \\
\hline 1974 & 2.00 & 5.25 & -0.04 & 90.3 & 87.7 & 79.2 & 87.8 & 0.525 & 0.503 & 0.628 & 0.578 \\
\hline 1975 & 2.10 & 5.01 & 0.00 & 90.4 & 87.8 & 79.3 & 87.9 & 0.540 & 0.503 & 0.632 & 0.572 \\
\hline 1976 & 2.30 & 5.07 & -0.01 & 90.5 & 87.9 & 79.6 & 88.0 & 0.554 & 0.523 & 0.633 & 0.592 \\
\hline 1977 & 2.30 & 4.80 & 0.05 & 90.6 & 88.0 & 79.6 & 88.1 & 0.553 & 0.528 & 0.634 & 0.576 \\
\hline 1978 & 2.65 & 5.20 & -0.03 & 90.7 & 88.2 & 79.8 & 88.2 & 0.569 & 0.536 & 0.640 & 0.592 \\
\hline 1979 & 2.90 & 5.45 & -0.08 & 90.7 & 88.2 & 79.8 & 88.2 & 0.565 & 0.523 & 0.646 & 0.589 \\
\hline 1980 & 3.10 & 5.33 & -0.06 & 90.8 & 88.4 & 80.1 & 88.4 & 0.574 & 0.538 & 0.646 & 0.593 \\
\hline 1981 & 3.35 & 5.18 & -0.03 & 90.8 & 88.4 & 80.1 & 88.4 & 0.577 & 0.550 & 0.659 & 0.605 \\
\hline 1982 & 3.35 & 4.74 & 0.06 & 90.8 & 88.4 & 80.1 & 88.4 & 0.581 & 0.567 & 0.678 & 0.627 \\
\hline 1983 & 3.35 & 4.48 & 0.12 & 90.8 & 88.4 & 80.1 & 88.4 & 0.601 & 0.587 & 0.690 & 0.652 \\
\hline 1984 & 3.35 & 4.30 & 0.16 & 90.8 & 88.4 & 80.1 & 88.4 & 0.630 & 0.608 & 0.692 & 0.662 \\
\hline 1985 & 3.35 & 4.13 & 0.20 & 90.9 & 88.4 & 80.1 & 88.4 & 0.631 & 0.601 & 0.685 & 0.644 \\
\hline 1986 & 3.35 & 4.00 & 0.23 & 90.9 & 88.4 & 80.2 & 88.5 & 0.633 & 0.612 & 0.690 & 0.662 \\
\hline 1987 & 3.35 & 3.93 & 0.25 & 90.9 & 88.5 & 80.2 & 88.5 & 0.617 & 0.609 & 0.706 & 0.670 \\
\hline 1988 & 3.35 & 3.80 & 0.28 & 90.9 & 88.5 & 80.3 & 88.5 & 0.618 & 0.626 & 0.713 & 0.667 \\
\hline 1989 & 3.35 & 3.66 & 0.32 & 90.9 & 88.5 & 80.3 & 88.6 & 0.619 & 0.612 & 0.713 & 0.674 \\
\hline 1990 & 3.80 & 3.99 & 0.23 & 90.9 & 88.5 & 80.3 & 88.6 & 0.640 & 0.607 & 0.699 & 0.673 \\
\hline 1991 & 4.25 & 4.25 & 0.17 & 90.9 & 88.4 & 80.2 & 88.5 & 0.638 & 0.627 & 0.687 & 0.682 \\
\hline 1992 & 4.25 & 4.10 & 0.20 & 90.9 & 88.4 & 80.1 & 88.5 & 0.650 & 0.628 & 0.697 & 0.698 \\
\hline 1993 & 4.25 & 4.00 & 0.23 & 90.9 & 88.4 & 80.2 & 88.5 & 0.650 & 0.637 & 0.719 & 0.698 \\
\hline 1994 & 4.25 & 3.90 & 0.25 & 90.9 & 88.4 & 80.1 & 88.5 & 0.666 & 0.652 & 0.726 & 0.722 \\
\hline 1995 & 4.25 & 3.82 & 0.27 & 90.9 & 88.4 & 80.2 & 88.5 & 0.678 & 0.630 & 0.705 & 0.745 \\
\hline 1996 & 4.75 & 4.17 & 0.19 & 90.9 & 88.4 & 80.2 & 88.5 & 0.675 & 0.616 & 0.698 & 0.733 \\
\hline 1997 & 5.15 & 4.40 & 0.13 & 90.9 & 88.4 & 80.2 & 88.5 & 0.689 & 0.617 & 0.702 & 0.739 \\
\hline 1998 & 5.15 & 4.31 & 0.15 & 90.9 & 88.4 & 80.2 & 88.5 & 0.698 & 0.610 & 0.706 & 0.723 \\
\hline 1999 & 5.15 & 4.25 & 0.17 & 90.9 & 88.4 & 80.2 & 88.5 & 0.702 & 0.621 & 0.702 & 0.731 \\
\hline 2000 & 5.15 & 4.16 & 0.19 & 90.9 & 88.4 & 80.2 & 88.5 & 0.696 & 0.623 & 0.693 & 0.721 \\
\hline
\end{tabular}

